\title{
Recent Advances on Biomarkers of Early and Late Kidney Graft Dysfunction
}

\author{
Marco Quaglia ${ }^{1}$, Guido Merlotti ${ }^{1}$, Gabriele Guglielmetti ${ }^{1}{ }^{\circledR}$, Giuseppe Castellano ${ }^{2}$ and \\ Vincenzo Cantaluppi ${ }^{1, *}$
}

1 Nephrology and Kidney Transplantation Unit, Center for Translational Research on Autoimmune and Allergic Disease (CAAD), Department of Translational Medicine, University of Piemonte Orientale (UPO), AOU Maggiore della Carità, via Gen. P. Solaroli, 17-28100 Novara, Italy; marco.quaglia@med.uniupo.it (M.Q.); guido.merlotti@maggioreosp.novara.it (G.M.); g.guglielmetti@maggioreosp.novara.it (G.G.)

2 Nephrology, Dialysis and Transplant Unit, Department of Medical and Surgical Sciences, University of Foggia, 71121 Foggia, Italy; giuseppe.castellano@unifg.it

* Correspondence: vincenzo.cantaluppi@med.uniupo.it

Received: 2 July 2020; Accepted: 27 July 2020; Published: 29 July 2020

check for updates

\begin{abstract}
New biomarkers of early and late graft dysfunction are needed in renal transplant to improve management of complications and prolong graft survival. A wide range of potential diagnostic and prognostic biomarkers, measured in different biological fluids (serum, plasma, urine) and in renal tissues, have been proposed for post-transplant delayed graft function (DGF), acute rejection (AR), and chronic allograft dysfunction (CAD). This review investigates old and new potential biomarkers for each of these clinical domains, seeking to underline their limits and strengths. OMICs technology has allowed identifying many candidate biomarkers, providing diagnostic and prognostic information at very early stages of pathological processes, such as AR. Donor-derived cell-free DNA (ddcfDNA) and extracellular vesicles (EVs) are further promising tools. Although most of these biomarkers still need to be validated in multiple independent cohorts and standardized, they are paving the way for substantial advances, such as the possibility of accurately predicting risk of DGF before graft is implanted, of making a "molecular" diagnosis of subclinical rejection even before histological lesions develop, or of dissecting etiology of CAD. Identification of "immunoquiescent" or even tolerant patients to guide minimization of immunosuppressive therapy is another area of active research. The parallel progress in imaging techniques, bioinformatics, and artificial intelligence (AI) is helping to fully exploit the wealth of information provided by biomarkers, leading to improved disease nosology of old entities such as transplant glomerulopathy. Prospective studies are needed to assess whether introduction of these new sets of biomarkers into clinical practice could actually reduce the need for renal biopsy, integrate traditional tools, and ultimately improve graft survival compared to current management.
\end{abstract}

Keywords: renal transplant; biomarkers; extracellular vesicles; acute rejection; chronic rejection; chronic allograft dysfunction; calcineurin-inhibitor nephrotoxicity; Polyomavirus associated nephropathy; immunosuppression

\section{Introduction}

General Features and Meaning of a Biomarker

A biomarker has been defined as "a characteristic that is objectively measured and evaluated as an indicator of a normal biological process, pathogenic process or pharmacological response to a therapeutic intervention" [1,2]. 
Transplanted kidney is currently monitored through a complex of clinical (e.g., GFR, proteinuria), immunological (e.g., DSA), instrumental (e.g., resistive index at Doppler ultrasound), and histological parameters. Overall these "traditional biomarkers" have many limits related not only to disease, but also to both nephrologists' and pathologists' skills. Even histological examination through renal biopsy, which remains the diagnostic golden standard criterion despite its invasiveness, is hampered by many drawbacks: low sensitivity (e.g., failure to detect subclinical acute rejection), low specificity due to heterogeneity of processes underlying the same lesion (e.g., uncertain interpretation of interstitial fibrosis-tubular atrophy, IFTA), lack of standardization (poor reproducibility, elevated inter-observer variability due to expertise-dependence) and of quantitative thresholds, sampling errors (e.g., failure to detect focal disorders such as Polyomavirus associated nephropathy, PVAN) [3].

New biomarkers have been the focus of intense research over the last decade to overcome these limits and improve allograft monitoring. Most of them are derived from "OMICs" revolution [4] and can be considered the cornerstone of precision medicine, which is based on a proactive approach and aims at predicting and preventing pathological processes by providing earlier and more extensive information than traditional ones [5].

In general, biomarkers can be classified into seven categories with different meaning and aims [5], outlined in Table 1.

Table 1. Biomarkers categories and their meaning in renal transplant.

\begin{tabular}{|c|c|}
\hline Type of Biomarker & Meaning in Renal Transplant \\
\hline Susceptibility or risk biomarker & $\begin{array}{l}\text { It estimates the risk of developing a condition (e.g., AR) in a } \\
\text { stable graft without any clinical sign of dysfunction }\end{array}$ \\
\hline Diagnostic biomarker & It identifies patients with a disease or a subset of it (e.g., AR type) \\
\hline Prognostic biomarker & $\begin{array}{c}\text { It estimates the likelihood of a clinical event or of disease } \\
\text { progression, staging severity of disease (e.g., severe rejection with } \\
\text { risk of graft loss) }\end{array}$ \\
\hline Predictive biomarker & $\begin{array}{l}\text { It estimates the likelihood of achieving a favorable response from } \\
\text { a therapy (e.g., Eculizumab for complement-fixing DSA) }\end{array}$ \\
\hline Monitoring biomarker & $\begin{array}{c}\text { It is serially measured in order to detect a change in evolution of } \\
\text { disease or signs of drug toxicity, or to detect exposure to } \\
\text { immunosuppressive drugs (e.g., TAC levels) }\end{array}$ \\
\hline Pharmacodynamic/response biomarker & $\begin{array}{l}\text { It verifies that a biological response has occurred after a drug } \\
\text { exposure (e.g., DSA MFI after treatment of ABMR) }\end{array}$ \\
\hline Safety biomarker & $\begin{array}{l}\text { It estimates presence and severity of drug-related toxicity } \\
\text { (e.g., CNI nephrotoxicity) }\end{array}$ \\
\hline
\end{tabular}

A plethora of new, non-invasive biomarkers measured in either urine or peripheral blood have been studied over the last years, mainly with a diagnostic and prognostic meaning, with different degrees of preclinical and clinical success. Some of them have been validated in independent cohorts and may be already employed in clinical decision-making when kidney biopsy is contraindicated or inconclusive. Other biomarkers, mainly represented by gene expression signatures, have been assessed in kidney tissue and appear to significantly expand information provided by traditional histology [6].

Different pathological processes can cause early and late KTx dysfunction and are outlined in Figure 1.

We herein reviewed the current literature on potential biomarkers in three main settings of KTx: ischemia reperfusion injury (IRI) and DGF, AR, and CAD. The latter includes biomarkers for chronic rejection, chronic Calcineurin-Inhibitor (CNI) nephrotoxicity, and PVAN. 


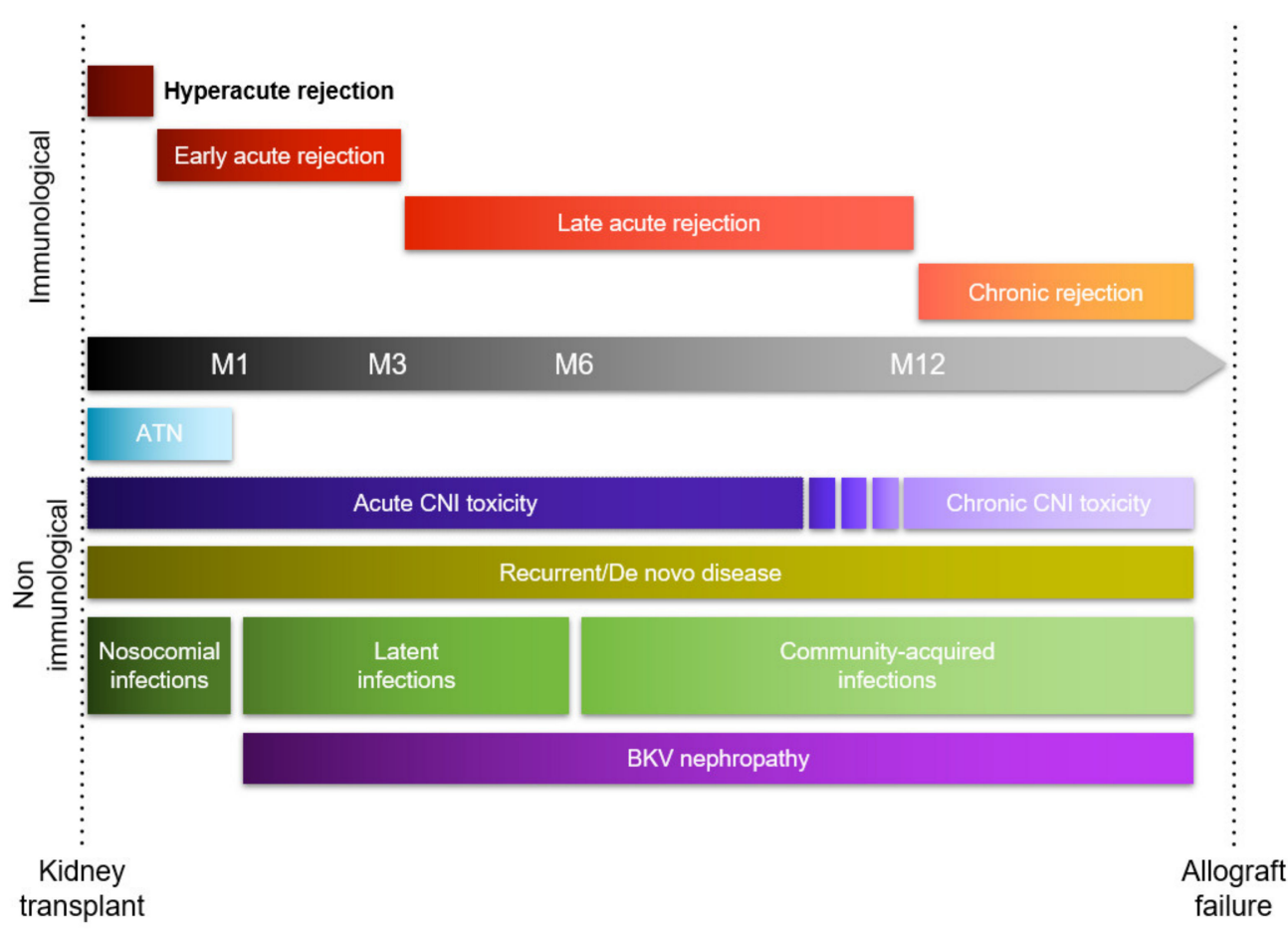

Figure 1. Timeline of early and late causes of graft dysfunction.

\section{IRI and DGF}

DGF is a common complication of KTx, which affects short and long-term outcomes, including risk of acute rejection and graft survival. It is often caused by IRI due to long cold ischemia time, especially in kidney from "extended-criteria" donors (ECD) and donation after cardiac death (DCD). The most commonly employed definition for DGF relies on the need for dialysis in the first week after KTx.

Biomarkers measured in the immediate post-Tx would be extremely useful to identify patients at risk of DGF and prevent this common complication, for example delaying start of CNI [7].

Ideally, biomarkers predicting DGF should be available either before KTx, in the donor, or immediately after it, in the recipient. The first option is especially interesting in the current era of increasingly higher risk ECDs [8], as accurate tools to assess kidney quality are needed to help allocate them to the most adequate recipient, or even discard them when considered unsuitable [9].

A lot of potential biomarkers of DGF have been studied and some of them have already been validated in independent cohorts (Tables 2 and 3). Some biomarkers have been analyzed in donor's biological fluids or in the graft (e.g., preservation fluid) before KTx, whereas most of them were studied in the recipient after KTx.

\subsection{Donor-Related Biomarkers}

Donor-related biomarkers can be measured in donor biological fluids, in graft preservation fluid, or in the perfusate of machine-perfused kidneys. 
Table 2. Potential biomarkers for DGF.

\begin{tabular}{|c|c|c|c|}
\hline Biomarker & Source & Main Features & Author \\
\hline Mitochondrial DNA & Donor plasma & It predicts DGF in DCD donors & Han F. et al. [10] \\
\hline Complement C5a & Donor urine & It predicts DGF & Schroppel B. et al. [11] \\
\hline miRNA & $\begin{array}{l}\text { Graft } \\
\text { preservation fluid }\end{array}$ & $\begin{array}{c}\text { Several miRNAs proposed as } \\
\text { biomarkers of DGF; miR-505-3p } \\
\text { validated in DCD grafts }\end{array}$ & $\begin{array}{c}\text { Gomez-Dos-Santos V. et al. [12] } \\
\text { Roest H. et al. [13] }\end{array}$ \\
\hline $\begin{array}{l}\text { LDH, NGAL and } \\
\text { MMP-2 }\end{array}$ & $\begin{array}{c}\text { Perfusate of } \\
\text { machine-perfused } \\
\text { kidneys }\end{array}$ & $\begin{array}{c}\text { Different levels according to type of } \\
\text { donor (DCD vs. DBD vs. LD), } \\
\text { reflecting degree of IRI }\end{array}$ & Moser M. et al. [14] \\
\hline $\begin{array}{l}\text { Exosomal mRNA for } \\
\text { NGAL and NGAL }\end{array}$ & $\begin{array}{c}\text { Perfusate of } \\
\text { machine-perfused } \\
\text { kidneys }\end{array}$ & They predict DGF & Cappuccilli M. et al. [15] \\
\hline$\pi \mathrm{GST}$ & $\begin{array}{c}\text { Perfusate of } \\
\text { machine-perfused } \\
\text { kidneys }\end{array}$ & It predicts DGF & Hall I. et al. [16] \\
\hline Furosemide stress test & - & $\begin{array}{l}\text { Clinical test: non-responsive patients } \\
\text { are at increased risk of DGF in the } \\
\text { following days }\end{array}$ & Udomkarnjananun S. et al. [17] \\
\hline $\begin{array}{l}\operatorname{miR} 182-5 p \\
\text { miR-21-3p }\end{array}$ & $\begin{array}{c}\text { Recipient's serum and } \\
\text { urine }\end{array}$ & They predict DGF & Wilflingseder J. et al. [18] \\
\hline miR146a-5p & $\begin{array}{l}\text { Recipient's peripheral } \\
\text { blood and renal tissue }\end{array}$ & Increased in both DGF and AR & Milhoransa P. et al. [19] \\
\hline $\begin{array}{l}\text { miR-9, miR-10a, } \\
\text { miR-21, miR-29a, } \\
\text { miR-221, miR-429 }\end{array}$ & $\begin{array}{l}\text { Recipient's urine } \\
\text { (first } 5 \text { days after KTx) }\end{array}$ & $\begin{array}{l}\text { This panel predicts DGF (validated } \\
\text { in an independent cohort) }\end{array}$ & Khalid U. et al. [20] \\
\hline NGAL & $\begin{array}{c}\text { Recipient's } \\
\text { serum/plasma } \\
\text { and urine } \\
\text { (first days after KTx) }\end{array}$ & $\begin{array}{l}\text { Both bNGAL and uNGAL predict } \\
\text { DGF and 1-year graft function, but } \\
\text { bNGAL is more accurate. } \\
\text { Urine NGAL predicts DGF also in } \\
\text { KTx from LD. }\end{array}$ & $\begin{array}{c}\text { Cappuccilli M. et al. [15] } \\
\text { Maier H. et al. [21] } \\
\text { Ramirez-Sandoval J. et al. [22] } \\
\text { Li Y. et al. [23] } \\
\text { Sahraei Z. et al. [24] }\end{array}$ \\
\hline Corin & Recipient's plasma & It is reduced in DGF & Hu X. et al. [25] \\
\hline $\begin{array}{l}\text { TLR-4 surface } \\
\text { expression }\end{array}$ & $\begin{array}{l}\text { Recipient's circulating } \\
\text { monocytes }\end{array}$ & $\begin{array}{l}\text { It is reduced in DGF and associated } \\
\text { with poor graft function at follow-up }\end{array}$ & Zmonarski S. et al. [26] \\
\hline Amylase & Recipient's serum & It increases in DGF & Comai G. et al. [27] \\
\hline Fascin and Vimentin & $\begin{array}{l}\text { Graft biopsy in } \\
\text { recipient }\end{array}$ & $\begin{array}{c}\text { Expression of these EndMT } \\
\text { biomarkers on microvasculature } \\
\text { correlated with long-term graft } \\
\text { function after DGF }\end{array}$ & Xu-Dubois Y-C. et al. [28] \\
\hline
\end{tabular}

\subsubsection{Donor Biological Fluids}

Elevated donor plasma mitochondrial DNA levels independently predicted DGF and correlated with 1-year graft survival in a cohort of DCD [10].

Following organ procurement, the role of innate immune system, such as Complement in IRI, has been extensively investigated. By generating effector molecules (C4b, C4d, C3b, iC $3 b$, $\mathrm{C} 3 \mathrm{dg}$, and $\mathrm{C} 3 \mathrm{~d}$ ) and anaphylatoxins (C3a, C5a), Complement can recruit granulocytes, monocytes, and other inflammatory cells to the site of ischemic injury and regulate activation of tubular epithelial cells and pericytes within the kidney. In addition, Complement factors can directly damage renal parenchymal cells by inducing tubular apoptosis, endothelial-to-mesenchymal transition (EndMT), pericytes-to-mesenchymal transition, and accelerated senescence [28-31]. EndMT deeply modifies endothelial cells, which acquires a mesenchymal phenotype and new properties, such as capacity to produce extracellular matrix (EM) and induce fibrosis. Biomarkers of EndMT have been the focus of recent research in different KTx areas and will be discussed in detail in following sections on recipient-related DGF biomarkers (Section 2.2.4) and on chronic rejection-IFTA within the setting of CAD (Section 4.1.3). 
Consistently, donor urinary C5a levels were independently associated with recipient post-transplant DGF, providing a potential rationale for complement-blocking therapies to prevent DGF in high risk patients [11].

\subsubsection{Graft Preservation Fluid}

Other studies have recently focused on analysis of potential biomarkers within graft preservation fluids, especially during hypothermic machine perfusion, with the rationale that their concentration may reflect organ viability and correlate with post-transplant renal function [12].

Cell-free microRNAs (miRNAs) show promise as biomarkers in several KTx settings. These are short non-coding RNAs that play a pivotal role in regulation of gene expression through epigenetic, transcriptional, and post-transcriptional mechanisms. They can be isolated, quantified and profiled by multiple platforms which can also characterize their target genes [32]. They have been studied in graft preservation fluid and proposed as viability biomarkers (miR-486-5p, miR-144-3p, miR-142-5p, and miR-144-5p) [12]; however, only miR-505-3p has been demonstrated to be an independent predictor of DGF in DCD grafts with high accuracy (AUC $=0.83$ ) and was confirmed in a validation cohort [13].

Of note, a significant percentage of miRNAs do not circulate free but are carried by EVs that have been detected in preservation fluid. These structures contain both donor-derived RNAs and selected miRNA which could be associated with graft function during the first seven post-operative days [33].

General features of EVs and their role as biomarkers of DGF will be discussed in more detail in the following paragraphs.

\subsubsection{Perfusate of Machine-Perfused Kidneys}

Proteomic analysis of perfusate from machine cold perfusion of graft was compared between different types of donor kidneys. LDH, neutrophil gelatinase-associated lipocalin (NGAL), and matrix metalloproteinase-2 levels were highest in DCD kidneys, followed by DBD and living-donor (LD) kidneys. Other molecules, such as periredoxin- 2 and $\alpha-1$ antitripsin, were also significantly different across the three groups, probably reflecting different degrees of IRI [14,15]. Exosomal mRNA for NGAL and NGAL concentration in the perfusate of machine-perfused kidneys were associated with DGF also in another study [15]. The $\alpha$ and $\pi$ iso-enzymes of glutathione S-transferase (GST) levels, measured from perfusate solution at the start and the end of machine perfusion, were analyzed in $428 \mathrm{KTx}$ recipients. While levels of both iso-enzymes significantly increased during this procedure, only $\pi$ GST levels at the end of machine perfusion were independently associated with DGF [16].

All the above-mentioned molecules represent potential biomarkers and therapeutic targets that may be useful in the setting of DGF, but still need to be validated.

\subsection{Recipient-Related Biomarkers}

\subsubsection{Furosemide Stress Test}

Furosemide stress test (FST) is a simple test to predict DGF in the post-transplant period. FST non-responsive patients (urine volume $<350 \mathrm{cc}$ after $4 \mathrm{~h}$ of Furosemide infusion) are at risk of developing DGF in the following days [17].

\subsection{2. miRNAs}

miRNAs, which we already analyzed as donor-derived biomarkers, have been the focus of several studies also in KTx recipients, representing both a biomarker and a potential therapeutic target [34-36]. MiR 182-5p and miR-21-3p in recipient's serum and urine correlated with DGF in one study [18]. MiR 146a-5p has been studied in renal tissue and peripheral blood during DGF. It was significantly increased in renal biopsy of patients with DGF as compared to stable recipients and those with AR and a similar trend was found in peripheral blood samples [19]. 
A urinary panel of six miRNAs (miR-9; miR-10a; miR-21; miR-29a; miR-221; miR-429) was consistently elevated in the first urine passed after $\mathrm{Tx}$ and in urine samples collected daily across the following five post-operative days in patients who developed DGF (ROC AUC $=0.94$ ). This panel was validated in an independent cohort [20].

In experimental IRI studies in mice, the expression of miR-139-5p in renal tissues of the IRI group was $40 \%$ lower than that of the sham-operated one. A set of candidate genes involved in regeneration and repair of kidney tissue, EM degradation and inflammation was also shown to be markedly overexpressed in this setting and may provide new biomarkers in the future [37].

\subsubsection{Neutrophil Gelatinase-Associated Lipocalin (NGAL) and Other Biomarkers}

NGAL has been the focus of many studies as a tubular injury biomarker for early prediction of DGF in KTx recipients. It has been studied both in graft perfusion fluid and in recipient's blood and urine.

Increased release from ischemia-injured tubular cells has been proved to discriminate patients at risk for AKI. Blood NGAL (bNGAL) — performed on serum/plasma — and urine NGAL (uNGAL) were shown to predict DGF in the early post-operative period, whereas its meaning as a perfusion fluid biomarker has already been discussed $[15,21]$.

In one study on $50 \mathrm{KTx}$ recipients from ECD, bNGAL levels at day 1 were significantly higher in the DGF group; of interest, NGAL accurately discriminated between slow and immediate graft function even within the non-DGF group. Furthermore, bNGAL levels preceded decrease in serum creatinine and allowed earlier TAC introduction in a "sequential" immunosuppressive protocol, shortening CNI-free window as compared to standard, creatinine-based management. Thus, bNGAL may help avoid unnecessary CNI underexposure in patients in which renal function is about to recover. The same study also shed light on NGAL function as a growth factor for tubular epithelial cells. In vitro, either hypoxia or TAC exposure induced its release from tubular epithelial cells and NGAL stimulated their regeneration after IRI and acute nephrotoxicity through an autocrine loop. However, chronic tubular stimulation by NGAL also appeared to promote epithelial-to-mesenchymal transition (EMT) and progression toward CKD. This pathological process will be discussed in detail in the following Section 4.1.3 concerning mechanisms of chronic rejection and IFTA. Overall these data suggest that NGAL levels might even predict a maladaptive repair with increased risk of progression from DGF to chronic loss of graft function [38].

Consistently, a more recent study prospectively assessed dynamic profile of bNGAL and UNGAL in 170 consecutive recipients within 7 days of Tx and found that their level on post-operative day 2 could accurately predict DGF. Multivariate analyses revealed donor age, serum and urinary NGAL were each independently associated with DGF $(p<0.001)$ [21].

A metanalysis first demonstrated that elevated serum and urine NGAL levels can predict DGF and 1-year graft function [22]; a second, more recent one, including 1036 patients from 14 studies, confirmed that both bNGAL - performed on serum/plasma - and uNGAL were robust biomarkers for DGF (AUC 0.91 and 0.95, respectively), with superior predictive value of bNGAL over uNGAL [23].

Of interest, urine NGAL post-operative modification in the first 24 hours were associated not only with DGF but also with worse renal outcomes at 2 years in terms of graft function and survival in LD KTx [24].

Several other biomarkers have been proposed in the setting of DGF.

A urinary tissue inhibitor of metalloproteinases-2 (TIMP-2), a validated biomarker for AKI, was reported to predict the occurrence and duration of DGF in DCD KTx recipients [39].

In a transcriptomic study on IRI mice, Corin was one of the most downregulated among more than 2200 differentially expressed genes and protein level of renal Corin was markedly reduced in IRI. Consistently, also plasma Corin concentrations were reduced in a small sample of recipients with DGF as compared to uncomplicated KTx recipients [25]. 
Expression of Toll-like (TLR-4) expression on circulating monocytes was reported to be lower in DGF patients and associated with poor graft function at follow-up [26].

An increase in serum Amylase ( $>20 \%$ ), especially if associated with increased Resistive Index ( $>0.7)$ predicted a higher incidence of DGF, longer hospital stay, and worse renal function at discharge in another study [27].

\subsubsection{BioMarkers of EndMT}

In a recent study biomarkers of partial microvasculature EndMT (Fascin and Vimentin) and of tubular EMT (Vimentin) were analyzed with immunoistochemistry in renal biopsies performed in early post-transplant due to DGF, showing ATN lesions. Extent of ATN was correlated with short and long-term (2 year) graft dysfunction only in the presence of partial EndMT (pEndMT) biomarkers expression, suggesting that early endothelial cell activation can identify patients at risk of incomplete recovery after DGF [28]. EndMt will be discussed in detail in the following Section 4.1.3 concerning mechanisms of chronic rejection and IFTA.

\subsubsection{EVs}

EVs is a general term which includes membrane structures of different size, released by cells after fusion of endosomes with the plasma membrane (exosomes), shed from plasma membrane (microvesicles), or released during apoptosis (apoptotic bodies). EVs are then taken up by neighboring or distant target cells (paracrine or endocrine effect) [40] and mediate a wide range of physiological and pathological processes, including renal disease [41]. EVs also exert pleiotropic, immunomodulatory roles in KTx [42]. Their bioactive cargo includes graft antigens, costimulatory/inhibitory molecules, cytokines, growth factors and, as discussed before, functional miRNAs that modulate expression of recipient cell target genes. Recent studies dissected this complex content, suggesting that some of these molecules may be potential biomarkers of DGF, paralleling recovery of renal and endothelial function. Even though initial evidence on dynamics of circulating EVs after KTx needs to be confirmed [43], this area of research appears to be promising.

Plasma and urinary EVs investigated as possible biomarkers of DGF in KTx are outlined in Table 3 [44-50].

Table 3. Extracellular vescicles (EVs) as potential biomarkers of DGF.

\begin{tabular}{ccc}
\hline Type of EV & Main Features & Author \\
\hline Plasma Endothelial EVs & $\begin{array}{c}\text { EVs level and their procoagulant activity } \\
\text { progressively decrease after KTx, } \\
\text { paralleling renal function recovery }\end{array}$ & Al-Massarani G et al. [44,45] \\
\hline Plasma Endothelial and platelet EVs & $\begin{array}{c}\text { Endothelial and platelet EVs size and level } \\
\text { progressively decrease after KTx, } \\
\text { paralleling renal function recovery }\end{array}$ & Martins S et al. [46] \\
\hline Urinary EVs & $\begin{array}{c}\text { NGAL expression in urinary EVs } \\
\text { correlated with DGF }\end{array}$ & Alvarez S et al. [47] \\
\hline Urinary CD 133+ EVs & Decreased level in recipients with DGF and \\
vascular damage & Dimuccio V et al. [48] \\
\hline Acquaporin-1 containing EVs & $\begin{array}{c}\text { Decreased urinary } \\
\text { Acquaporin-1-containing EVs in DGF }\end{array}$ & Asvapromtada S et al. [50] \\
\hline
\end{tabular}

\section{AR}

Potential biomarkers of acute antibody-mediated rejection (ABMR) and T-cell mediated rejection (TCMR) are reported in detail in Tables 4-6. 
Table 4. Potential biomarkers for acute rejection (AR).

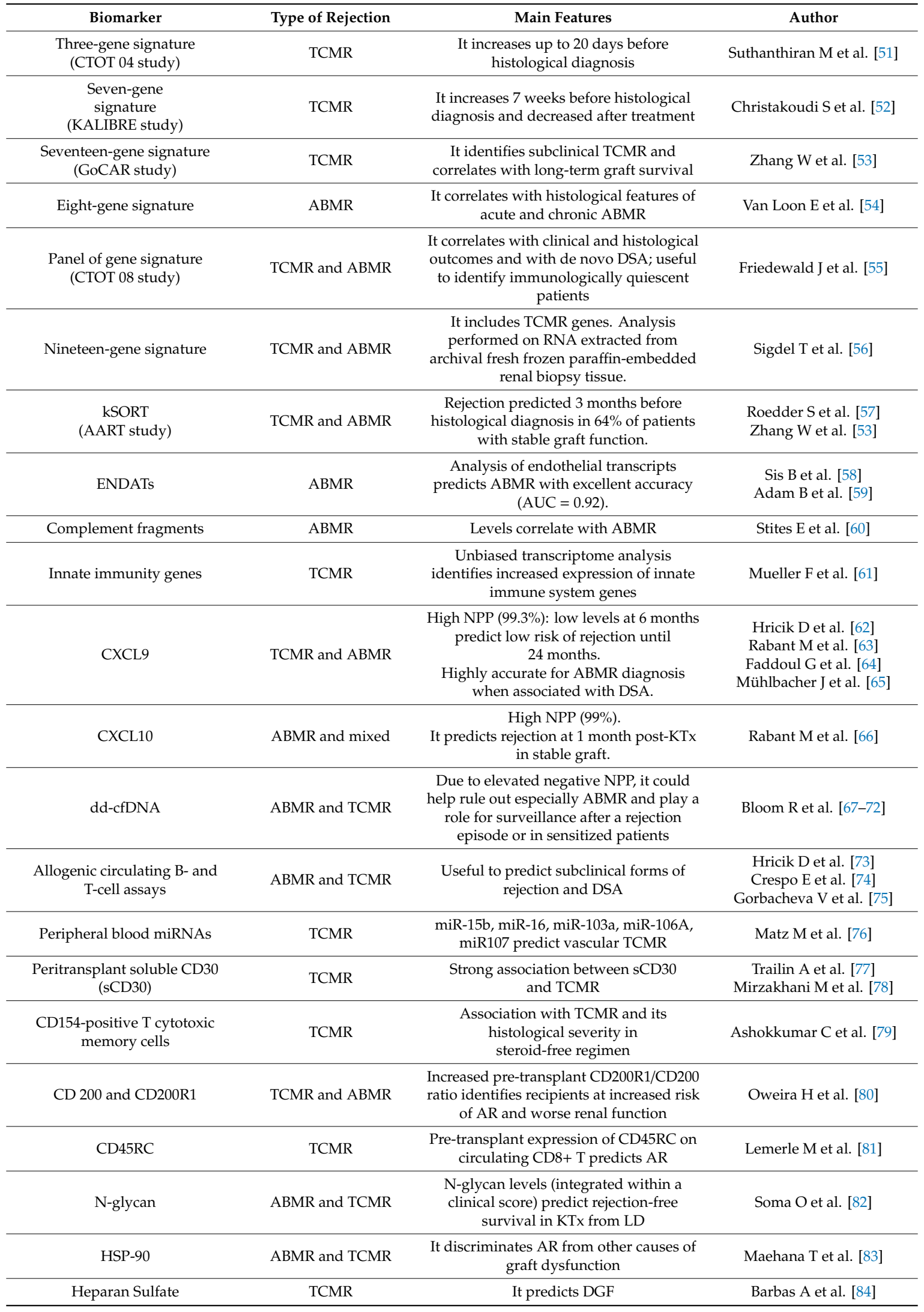




\subsection{Transcriptomic Studies}

\subsubsection{Urine and Peripheral Blood Transcriptomics}

The CTOT 04 trial has analyzed mRNA transcripts in urinary sediment cells and identified a three-gene signature (CD3 $\varepsilon$ mRNA, CXCL10 mRNA, and 18S rRNA) predicting TCMR up to 20 days before biopsy-proven diagnosis [51]. A more recent study by the same group analyzed gene expression in urinary cells and renal biopsies during $A R$ and identified unique and shared gene signatures associated with biological pathways involved in TCMR and ABMR. Furthermore, they demonstrated the enrichment of biopsy gene signature in urinary cells and of immune cell types in urine compared with renal tissue. These findings support the hypothesis that urine gene expression patterns can reflect and even amplify ongoing renal tissue immune pathways and may help diagnose rejection and monitor its dynamics [85]. This is consistent with evidence from previous studies suggesting that graft can sort renal tissue infiltrating cells in urine as an in vivo flow cytometer [86].

Several studies have tried to identify a peripheral blood gene expression signature to diagnose subclinical AR at an early stage.

Christakoudi $S$ et al. analyzed expression of 22 literature-based genes in peripheral blood samples of patients from Kidney Allograft Immune Biomarkers of Rejection Episodes (KALIBRE) study and identified a seven-gene TCMR-signature (IFN- $\gamma$, IP-10, ITGA4, MARCH8, RORc, SEMA7A, WDR40A) which allowed diagnosis of AR 7 weeks before renal biopsy and correlated with response to therapy [52].

Zhang W et al. focused on patients with subclinical TCMR (protocol biopsy at third month) in KTx recipients from Genomics of Chronic Allograft Rejection (GoCAR) study [87] and identified a 17-gene peripheral blood signature which characterized ongoing subclinical TCMR and predicted an increased risk of clinical TCMR at 24 months and decreased graft survival [53].

A peripheral blood mRNA assay based on eight genes (CXCL-10, FCGR1A, FCGR1B, GBP1, GBP4, IL15, KLRC1, TIMP1) was developed in a multicenter, prospective study and correlated with histological features of acute and chronic ABMR (microvascular inflammation, transplant glomerulopathy) but not of TCMR. Diagnostic accuracy was high (ROC AUC 79.9\% $p<0.0001$ ), even in the setting of stable graft function [54].

A blood molecular biomarker based on multiple gene expression signatures was designed to distinguish "immunological quiescence" from subclinical AR in a multicenter study (CTOT-08). This correlated with clinical (AR, renal function) and histological outcomes (IFTA) and with de novo DSA. This biomarker was validated with surveillance biopsies data and proved to be especially useful in ruling out subclinical rejection (NPP: 78-88\%) [55].

In a multi-center "Assessment of Acute Rejection in renal Transplant (AART)" study, peripheral blood transcriptome analysis identified a 17-gene signature called "Kidney Solid Organ Response test" (kSORT), which predicted both TCMR and ABMR up to 3 months before histological diagnosis in an independent prospective cohort. This tool is characterized by a high accuracy in predicting AR, especially when compared with performance of other biomarkers in the same setting (AUC =0.94; sensitivity: 83\%, specificity: 90.6\%; PPV: 93,2\%) [57,88].

kSORT has also been used in association with an IFN $\gamma$ Elispot in the ESCAPE study, resulting in a higher PPP (AUC > 0.85) for subclinical TCMR and ABMR [74].

Peripheral blood transcriptomic analysis allowed to build a classification model capable of discriminating ABMR from accommodation in ABO-incompatible kidney transplants [89].

A blood test (TruGraf v1) has been developed to study a set of microarray-based gene expression in order to discriminate patients with a stable graft and immunological quiescence ("Transplant Excellence") from those with renal dysfunction or AR. This tool was proposed as a tool to avoid unnecessary surveillance biopsies on the basis of high accuracy in detecting AR (74\%) and high NPP (90\%) [90]. The value of serial TruGraf testing to confirm immunoquiescence and avoid surveillance biopsies has been confirmed in a recent study [91]. 


\subsubsection{Renal Tissue Transcriptomics}

Sigdel T et al. analyzed tissue expression of selected 19 target genes, including those previously identified in tissue common rejection module (tCRM). Interestingly, they employed RNA extracted from archival fresh frozen paraffin-embedded renal biopsy tissue. Eight genes were related to specific cellular infiltrates, whereas the others reflected a "graft inflammation score" based on tCRM. This set of genes allowed to distinguish biopsies of stable grafts from those of recipients with AR and even borderline inflammation [56].

Molecular patterns such as upregulation of intrarenal complement regulatory genes discriminate accommodation from subclinical antibody-mediated rejection in AB0-incompatible KTx [92].

An intra-graft mRNA transcriptomic landscape of TCMR has been outlined through computational analysis and has shown an increased expression of innate immunity genes, such as genes for pattern recognition receptors, and a decreased expression of calcineurin, suggesting inadequate immunosuppression, as compared to stable graft [61].

Real time central molecular assessment of changes in mRNA expression in graft tissue through microarrays is the basis of "molecular microscope diagnostic system", which predicted risk of AR and graft failure with greater precision than conventional biopsy. Pathogenesis-based transcripts sets (PBTs) which segregate together and characterize different processes (e.g., IGF-gamma expression, T cell infiltrates), were employed to define "classifiers" which predict molecular phenotype, quantifying its likelihood with a score. Of importance, this approach has been validated in several independent cohorts $[93,94]$.

Other studies have shown that endothelial associated transcripts (ENDATs) in biopsies of DSA-positive patients can reveal ABMR even in the absence of C4d positivity [58] and that ABMR-related endothelial genes RNA transcripts are expressed before histological onset of lesions, allowing excellent identification (AUC $=0.92$ ) and potentially early, preemptive treatment of rejection [59].

Finally, single-cell transcriptomics can comprehensively describe cell types and states in a human kidney biopsy and was employed to analyze immune response in mixed rejection: 16 distinct cell types were identified, including different sub-clusters of activated endothelial cells [95]. This cell-based approach may provide a wealth of new biomarkers for ABMR in the future [96].

\subsection{Complement-Related Biomarkers}

Complement system is deeply involved in ABMR and can therefore provide potential biomarkers related to this process.

The C4d deposition has been considered the gold standard for ABMR diagnosis for several years, indicating activation of Classical pathway of Complement; however, all Complement pathways have been proved to be involved in ABMR, leading to recruitment and activation of leukocytes such as Natural Killer cells, monocytes/macrophages, and lymphocytes [97].

Bobka S. et al. also demonstrated an increased Complement activation in pre-transplant biopsies from diabetic, hypertensive, or smoking donors, suggesting a predictive value of Complement activation in donor biopsies for later outcome [98]. Expression of these Complement components at time of diagnosis of ABMR was associated with higher serum creatinine and more severe morphological changes. As further evidence, $\mathrm{C} 5$ blockade prevented ABMR and stabilized long-term renal function.

In addition, EVs shed by endothelial cell expressing $\mathrm{C} 4 \mathrm{~d}\left(\mathrm{CD} 144^{+} \mathrm{C} 4 \mathrm{~d}^{+}\right)$are increased in $\mathrm{ABMR}$ and correlate with its severity and response to treatment [99] and plasma levels of complement activation fragments C4a and Ba are increased in ABMR [60]. Single nucleotide polymorphisms (SNP) of complement $\mathrm{C} 3$ gene have also been found to correlate with ABMR [100]. Upregulation of intrarenal complement regulatory genes and complement transcripts in peripheral blood of ABO-incompatible KTx has already been discussed in "Transcriptomic Studies" [92]. Altogether, these data support the use of Complement Factors as potential biomarkers in ABMR. 


\subsection{Urinary and Serum Chemokines}

IFN- $\gamma$ induced urinary C-X-C motif chemokine ligand 9 (CXCL9) and 10 (CXCL10) chemokines are associated with Th-1 immune response and involved in $\mathrm{T}$ cell recruitment in inflammatory processes. They are promising as biomarkers for TCMR and ABMR [62,66].

Low levels are associated with immunological quiescence, as shown by their very high NPP, which makes them an ideal tool to rule out rejection, including subclinical ones, and to identify transplant recipients at low immunological risk [63]. This was especially evident for CXCL 9 (CTOT-01 study), which was associated with acute TCMR within the first year.

However, a subsequent study with a longer follow-up (CTOT-17) showed that changes in eGFR between 3 or 6 months and 24 months better predicted 5-year graft loss than CXCL-9 measurement [64].

Association of urinary CXCL10-to-creatinine ratio with DSA improved identification of ABMR and prediction of graft loss. In a recent study, higher blood and urine levels of both CXCL9 and CXCL10 were found in ABMR, but urinary CXCL9 was the most accurate biomarker of rejection (AUC of ROC: 0.77 ) and-if measured in combination with immunodominant DSA mean fluorescence intensity (MFI) — it allowed a net reclassification increase of 73\% compared to DSA MFI alone [65].

Interestingly, even CXCL9 and CXCL10 baseline recipient's serum levels assessed before KTx may predict AR [101,102].

Additionally, urinary CXCR3-the receptor for CXCL9 and CXCL10, expressed on activated T-lymphocytes-was shown to detect subclinical inflammation and correlate with evolution towards chronic damage; of interest, its level decreased after immunosuppression intensification [103].

In another study, serum concentration of chemokine CXCL13, a B lymphocyte chemoattractant, was significantly higher in TCMR than in stable graft and in borderline rejection; furthermore, a marked increase (>5-fold) was found in patients developing AR within first post-transplant week and correlated with entity of B cell infiltration in renal biopsy. A similar correlation was found in a mouse model of TCMR, indicating that CXCL13 serum levels may be a marker of B cell-involvement in TCMR, identifying a severe subset of this type of rejection [104].

On the whole, growing evidence points to a role of urinary and serum chemokines as biomarkers of both types of AR.

\subsection{Other Potential Urinary Biomarkers}

Other urinary molecules have been proposed as markers of AR.

High urinary $\pi$-GST values at postoperative day 1 discriminated AR (sensitivity, $100 \%$; specificity, $66.6 \%$ ) as well as between DGF from normal-functioning grafts (sensitivity, $100 \%$; specificity, $62.6 \%$ ). Similarly, $\alpha$-GST values $>33.97 \mathrm{ng} / \mathrm{mg}$ uCrea identified AR, with a lower sensitivity (77.7\%) but optimal specificity $(100 \%)$ [105].

Urinary untargeted metabolomic profiling led to identification of a panel of five potential biomarkers (guanidoacetil acid, methylimidazolacetic acid, dopamine, 4-guanidobutyric acid, and L-tryptophan), which discriminated between TCMR and stable graft (ROC curve AUC: sensitivity 90\%; specificity $84.6 \%$ ) [106].

\section{5. $d d-c f D N A$}

Small fragments of cell-free DNA, released from graft cells into the recipient circulation due to cell death or injury, have been proposed as biomarkers of AR.

While dd-cf DNA represents on average $0.34 \%$ of total cf-DNA in plasma of stable KTx recipients, levels are increased during AR and, to a lesser extent, acute pyelonephritis and ATN.

A kinetic pilot study of dd-cfDNA after Tx showed high median level in the immediate post-Tx hours (around 20\%), rapidly decreasing on the first day (around 5\%) and then stabilizing below 1\% [107].

In the DART (Diagnosing Active Rejection in Kidney Transplant Recipients) trial, Bloom RD et al. first reported higher dd-cfDNA levels in patients with acute (TCMR Banff $>$ IB and ABMR) and chronic 
active rejection and identified a $1 \%$ threshold to discriminate these patients from stable ones. This test was characterized by elevated NPP ( $84 \%)$ and a lower PPP $(61 \%)$, suggesting that $<1 \%$ percentage of dd-cfDNA could be used to rule out rejection, especially ABMR. Coexistence of DSA increased PPP to $85 \%$. Furthermore, dd-cfDNA levels not only increased before changes in serum creatinine but also decreased after rejection treatment, suggesting that longitudinal monitoring of this biomarker could be useful after a rejection episode, possibly limiting need for surveillance biopsies [67].

In a subsequent work, Huang $E$ et al. [68] demonstrated that a lower dd-cfDNA threshold of $0.74 \%$ could reliably identify ABMR — but not TCMR—in a group of immunologically high-risk patients undergoing indication biopsies, increasing NPP to $100 \%$.

However, other authors suggested comparable performance of dd-cfDNA in diagnosing ABMR and TCMR, using a different quantification methodology [69].

Absolute quantification of dd-cfDNA (copies/mL) showed superior performance in discriminating BPAR as compared to dd-cfDNA percentage and also seemed to identify a subset of patients with inadequate Tacrolimus levels and subclinical immunological damage in a prospective observational study [70].

Of interest, dd-cfDNA diagnostic capacity for ABMR appears to improve when applied to DSA-positive recipients, suggesting a preferential employment in monitoring highly sensitized patients [71].

Determination of dd-cfDNA can be unreliable in case of recent (within 1 month) whole blood transfusion and falsely positive within $24 \mathrm{~h}$ of a renal biopsy; it should also not be employed to monitor a second KTx as release from previous graft could alter its levels. Falsely positive results can also occur in the case of ATN and acute pyelonephritis and type of donor also affects levels (higher levels in cadaveric vs. LD), probably reflecting difference in degree of initial ischemic damage and inflammation [72].

Despite these issues, dd-cfDNA remains a promising biomarker and it has been proposed as a surrogate diagnostic ABMR criterion in DSA-negative forms [108].

Furthermore, recent studies suggest that dd-cfDNA determination could also have a broader meaning beyond AR diagnosis, reflecting graft injury and consequently exerting a negative impact on several long-term outcomes [109]. Of interest, a multicentric study on patients with initial TCMR (TCMR 1A and borderline lesions) showed that dd-cfDNA levels above $0.5 \%$ were effective in stratifying risk of eGFR decline, de novo DSA development and further AR episodes [110]. Consistently, emerging evidence indicates that levels of dd-cfDNA increase before onset of de novo DSA (both HLA-DSA and non-HLA DSA) and eGFR decline [73], suggesting that dd-cf DNA itself is immunogenic and can trigger subclinical inflammation, initiating an immune response [75].

Urinary levels of cell-free mitochondrial DNA during early post-transplant phase have also been reported to correlate with AR, DGF and short-term renal function [76].

\subsection{Allogenic Circulating B-Cell and T-Cell Assays}

Peripheral circulating donor HLA-specific memory B cells quantified by enzyme-linked immunospot (ELISPOT) [77] and serum B-cell activating factor level on post-operative day 7 [78] both predicted ABMR, especially in DSA-positive recipients.

Pre-transplant $\mathrm{T}$ cell alloreactivity can be assessed with a donor-specific IFN- $\gamma$ ELISPOT which measures IFN- $\gamma$ release by recipient $\mathrm{T}$ cells in response to donor antigens. IFN- $\gamma$ ELISPOT intensity appears to correlate with development of subclinical TCMR, ABMR, and DSA [79,80].

\subsection{Peripheral Blood miRNAs}

General features and meaning of miRNAs have already been dealt with in the paragraph on DGF biomarkers. A panel of five peripheral blood miRNAs-miR-15b, miR-16, miR-103a, miR-106A, miR107—was shown to improve sensitivity of diagnosis of vascular TCMR [81]. 


\subsection{Immune Cells Biomarkers}

Peri-transplant soluble CD30 (sCD30), a marker of activated T-cell mediated immunity, has been reported to predict early AR [82].

A recent metanalysis on 18 studies (1453 total patients) has confirmed a strong association between sCD30 and AR, especially for KTx from deceased donors [83].

CD154-positive T cytotoxic memory cells were associated with acute TCMR and its histological severity in a small cohort of KTx recipients receiving steroid-free TAC after alemtuzumab induction [84].

Pre-transplant, baseline levels of CD200 (a protein belonging to immunoglobulin superfamily) and CD200R1 (its myeloid-cell specific receptor, which mediates inhibitory signals) have been analyzed in a monocentric cohort of 125 KTx recipients; an increased pre-transplant CD200R1/CD200 ratio identified recipients at increased risk of $A R$ and worse renal function at the 3rd and 6th month after KTx [111].

Additionally, pre-transplant expression of CD45RC on circulating CD8+ T lymphocytes predicted AR (mainly TCMR); a percentage of CD8+CD45RC T cells above $58.4 \%$ was independently associated with a 4-fold increase in the risk of AR [112].

\subsection{Non-HLA DSA}

Donor human leukocyte antigen (HLA)-specific antibodies were initially identified as a major cause of ABMR. This type of DSA has been extensively studied and represents an established, "traditional" biomarker of ABMR, which is beyond the scope of this review [113,114].

In more recent years, preformed and de novo non-HLA specific DSA targeting G-protein coupled receptors expressed on graft glomerular endothelium have been the focus of intense research, as they may account for a significant proportion of HLA-DSA negative acute and chronic ABMR [115-117]. They include a wide range of autoantibodies against different antigens, all of which represent potential biomarkers for ABMR [118] (Table 5).

Antibodies against type 1 receptor for Angiotensin 2 (AT1R) and Endothelin type A receptor (ETAR) are the most studied non-HLA, activating antibodies and appear to exert their effect either alone or in synergy with DSA. After binding to their receptors, these autoantibodies phenotypically modify and activate endothelial cell by triggering different intracellular pathways. They probably represent a bridge between allo- and autoimmunity within rejection, as these two components can interact and amplify one another [119]. Pre-transplant antibodies against AT1R and ETAR may identify a subset of patients at higher risk for acute and chronic rejection and graft loss, independent of HLA-directed alloimmune response [120,121], possibly even in a setting of low-immunological risk such as KTx from LD [122-124]. Pre-transplant antibodies against AT1R have also been associated with more severe microvascular inflammation histological lesions as compared to negative patients [125].

Anti-vimentin antibodies detected before KTx, probably reflecting previous endothelial damage occurred during hemodialysis, have also been associated with graft dysfunction [126].

Anti-Perlecan/LG3 antibodies are produced as a consequence of Perlecan release from injured endothelial cells [127]. They are highly prevalent in hypersensitized patients [128] and have been associated with acute ABMR, DGF, and reduced long term survival $[129,130]$.

Anti-endothelial cell antibodies (AECA), which include a wide range of autoantibodies against several surface antigens, may also prove to be a source of rejection biomarkers [131,132].

In general, AECA have been associated with acute and chronic rejection and with early graft dysfunction in different types of solid organ transplant, including heart and kidney. De novo AECA seem to be more strongly associated with ABMR than preformed ones [133].

Identification of their target antigens is complex, and their precise meaning must still be elucidated for most of them, as they could represent biomarkers of past vascular injury or, on the contrary, be active contributors to microvascular inflammation [134].

However, some specific types of AECA have already been clinically characterized and show promise as biomarkers of endothelial injury. Their antigenic targets are Endoglin, Fms-like tyrosine kinase-3 ligand (FLT3-L), EGF-like repeats and discoidin I-like domains 3 (EDIL-3), and intercellular 
adhesion molecule 4 (ICAM-4), all involved in endothelial cell activation and leukocyte adhesion and margination. AECA have been associated with de novo DSA, ABMR, and early transplant glomerulopathy [131]. More recently, also anti-keratin-1 (KRT-1) antibodies were found to be associated with an increased risk of AR [132].

Finally, development of antibodies directed against tissue-specific self-antigens, such as Fibronectin (FN) and Collagen type IV (Col IV), increases the risk of AR in pancreas-kidney transplantation (PKT) [135] and transplant glomerulopathy in KTx [136]. These autoantibodies probably reflect breakdown of tolerance towards self-antigens, as suggested by detection of self-Ag-specific IFN- $\gamma$ and IL-17 secreting T-cells in the same patients. Therefore, they could provide a biomarker of a tissue-specific autoimmune component of rejection.

In the near future, improved identification and characterization of non-HLA DSAs may help better classification of ABMR subphenotypes and provide diagnostic and prognostic biomarkers and potentially even indication for preemptive specific therapies in this subset of patients [124].

Table 5. Non-HLA DSA as a potential biomarker for antibody-mediated rejection (ABMR).

\begin{tabular}{|c|c|c|}
\hline Biomarker & Main Features & Author \\
\hline Anti-AT1R & $\begin{array}{l}\text { Pre-transplant levels associated with, } \\
\text { acute and chronic ABMR, severity of } \\
\text { microvascular inflammation, graft } \\
\text { dysfunction, and graft loss }\end{array}$ & $\begin{array}{c}\text { Dragun D et al. [119] } \\
\text { Philogene MC Hum Imm 2019 [120] } \\
\text { Sas-Strozik et al. [121] } \\
\text { Shinae Y et al. [122] } \\
\text { DF Pinelli et al. [123] } \\
\text { MA Lim et al. [125] }\end{array}$ \\
\hline Anti-ETAR & $\begin{array}{l}\text { Pre-transplant levels associated with } \\
\text { acute and chronic ABMR graft } \\
\text { dysfunction and graft loss }\end{array}$ & $\begin{array}{c}\text { Philogene MC et al. Hum Imm } 2019 \text { [120] } \\
\text { Shinae Y et al. [122] } \\
\text { DF Pinelli et al. [123] } \\
\text { Jackson AM et al. [131] }\end{array}$ \\
\hline Anti-Vimentin & $\begin{array}{l}\text { Pre-transplant levels associated with } \\
\text { graft dysfunction }\end{array}$ & Dyvanian T et al. [126] \\
\hline Anti-Perlecan & $\begin{array}{l}\text { Highly prevalent in hypersensitized } \\
\text { patients. Pre-transplant levels } \\
\text { associated with increased risk of DGF, } \\
\text { acute ABMR, and reduced long-term } \\
\text { function }\end{array}$ & $\begin{array}{l}\text { Dieudè M et al. [127] } \\
\text { Riesco L et al. [128] } \\
\text { Padet L et al. [129] } \\
\text { Yang B et al. [130] }\end{array}$ \\
\hline AECA & $\begin{array}{l}\text { They include a variety of antibodies } \\
\text { against endothelial antigens (Endoglin, } \\
\text { FLT-3, EDIL-3, ICAM-4, KTR-1) and } \\
\text { correlate with increased risk of ABMR }\end{array}$ & $\begin{array}{c}\text { Jackson AM et al. [131] } \\
\text { Guo X et al. [132] } \\
\text { Sanchez Zapardiel E et al. [133] }\end{array}$ \\
\hline Anti-FN and Col-IV & $\begin{array}{c}\text { De novo development increases risk of } \\
\text { AR (PKT) and transplant } \\
\text { glomerulopathy (KTx) }\end{array}$ & $\begin{array}{l}\text { Angaswamy N et al. [135] } \\
\text { Gunasekeran M et al. [136] }\end{array}$ \\
\hline
\end{tabular}

\subsection{Other Biomarkers}

Another potential biomarker is serum N-glycan determination, performed at days 1 and 7 post-Tx and integrated in a clinical score (including age, gender, and immunological risk factors). A higher sum of scores at days 1 and $7(>0.5)$ predicted graft rejection $(A U C=0.87)$ and correlated with long-term rejection-free survival in a cohort of LD Tx recipients [137].

Heat shock protein 90 (HSP-90), a molecular chaperon protein released into serum by damaged cells, was found to be significantly elevated in plasma of KTx with AR as compared to stable graft and other pathological conditions (chronic rejection, CNI nephrotoxicity, Polyomavirus nephropathy) and returned to baseline after immunosuppressive treatment [2,138].

Heparan Sulfate plasma levels are increased in TCMR compared to stable graft, due to release from EM during graft T-cell infiltration [2,139]. 
Many other urinary and plasmatic proteins could be potential biomarkers of rejection but deserve to be further studied: among these, C-C motif chemokine ligand 2 (CCL2), NGAL, IL-18, cystatin C, KIM-1, T-cell immunoglobulin and mucine domains-containing protein 3 (TIM3), alpha-1 antitrypsin (A1AT), alpha-2 antiplasmin (A2AP), serum amyloid A (SAA), and apolipoprotein CIII (APOC3) [2,140,141].

\subsection{EVs}

General features and meaning of EVs have already been dealt with in the paragraph on DGF biomarkers.

EVs represent a versatile tool given the huge variety of mediators included in their cargo. Therefore, potential applications of plasma and urinary EVS as biomarkers have also been studied in AR, as outlined in Table 6. In some studies, EVs levels have been considered as biomarkers themselves [99], whereas a set of specific molecules included in their cargo proved to be a potential biomarker of AR in others [142-146].

Table 6. EVs as potential biomarkers of AR.

\begin{tabular}{|c|c|c|c|}
\hline Type of EV & Type of Rejection & Main Features & Author \\
\hline $\begin{array}{l}\text { Plasma C4d+CD144+ } \\
\text { endothelial EVs }\end{array}$ & ABMR & $\begin{array}{c}\text { Levels correlate with ABMR presence } \\
\text { and severity and decrease after } \\
\text { successful treatment }\end{array}$ & Tower C et al. [99] \\
\hline Plasma endothelial EVs & ABMR & $\begin{array}{l}\text { A combination score based on } 4 \\
\text { mRNA transcripts overexpressed in } \\
\text { EVs of patients with ABMR predicts } \\
\text { imminent rejection in HLA- } \\
\text { sensitized patients }\end{array}$ & Zhang H et al. [142] \\
\hline Plasma endothelial EVs & ABMR & $\begin{array}{l}\text { Levels increase in ABMR and } \\
\text { decrease after treatment in the early } \\
\text { post-transplant; however, they are } \\
\text { also influenced by renal } \\
\text { function recovery }\end{array}$ & Qamri Z et al. [143] \\
\hline Urinary EVs & TCMR & $\begin{array}{l}\text { A total of } 11 \text { protein enriched in } \\
\text { urinary EV in patients with TCMR }\end{array}$ & Sigdel T et al. [144] \\
\hline Urinary EVs & TCMR & $\begin{array}{l}\text { A total of } 17 \text { protein enriched in } \\
\text { urinary EV in patients with TCMR; } \\
\text { Tetraspanin- } 1 \text { and Hemopexin } \\
\text { proposed as biomarkers }\end{array}$ & Lim J et al. [145] \\
\hline Urinary EVs & TCMR & $\begin{array}{c}\text { High levels of CD3 + EVs released by } \\
\text { T-cell in urine are strongly associated } \\
\text { with TCMR }\end{array}$ & Park J et al. [146] \\
\hline
\end{tabular}

\section{Chronic Allograft Dysfunction (CAD)}

Chronic allograft dysfunction is the main cause of long-term graft loss [147].

Different entities can be accounted for this picture, with chronic ABMR (cABMR) playing a predominant role in most cases [148].

However, other components can be represented by CNI nephrotoxicity, PVAN, de novo or relapsing glomerulonephritis. Many studies have focused on biomarkers for late graft dysfunction as a global entity, while others have tried to identify specific biomarkers to dissect each of these components.

In general, defining specific biomarkers for CAD is difficult, because molecular fingerprints of acute and chronic rejection are overlapping, partly reflecting similar mechanisms. Some authors propose a "threshold effect", with AR developing when intensity of alterations is high and chronic rejection expressing a less important degree of alterations [2]. For example, Complement is not only involved in ABMR, as described in a previous paragraph, but also plays a pivotal role as mediator of tubular senescence $[28,30,149]$ and interstitial fibrosis, premature aging phenomena that characterize progression to chronic damage [150]. C3a, C5a, and the terminal C5b-9 complex can each amplify damage during CKD progression. Anaphylatoxins bind to their specific receptors inducing pro-inflammatory and fibrogenic activity on tubular and endothelial cells [151,152], pericytes [153], 
and resident fibroblasts, whereas C5b-9 complex can regulate production of pro-fibrotic and pro-inflammatory cytokines [97]. Collectively, these data indicate that uncontrolled Complement activation may result in maladaptive tissue repair with irreversible development of renal fibrosis and aging. Identification of biomarkers of CAD is therefore challenging due to coexistence of acute and chronic processes, but it would be extremely useful for a differential diagnosis [154].

\subsection{Chronic Rejection and IFTA}

Potential biomarkers for chronic rejection and IFTA are outlined in Table 7. IFTA is found in around $25 \%$ of 1-year biopsies and correlates with decreased graft survival when histological evidence of inflammation is present.

Table 7. Potential biomarkers for chronic rejection and interstitial fibrosis-tubular atrophy (IFTA).

\begin{tabular}{|c|c|c|}
\hline Biomarker & Main Features & Author \\
\hline $\begin{array}{l}\text { Set of genes related to fibrosis (i.e., } \\
\text { TGF } \beta \text { ), extracellular matrix deposition } \\
\text { and immune response }\end{array}$ & Upregulated in IFTA & Mas V et al. [155] \\
\hline $\begin{array}{l}\text { 4-gene urinary signature (mRNA for } \\
\text { vimentin, NKCC2, E-cadherin, } \\
\text { and } 18 \mathrm{~S} \text { rRNA) }\end{array}$ & $\begin{array}{l}\text { It predicts evolution of chronic } \\
\text { rejection towards IFTA }\end{array}$ & Lee J. et al. [86] \\
\hline $\begin{array}{l}\text { 13-gene renal tissue signature } \\
\text { (GoCAR study) }\end{array}$ & $\begin{array}{l}\text { It predicts CAD at the } 12 \text { th month } \\
\text { even with normal histology at the } \\
\text { 3rd month }\end{array}$ & O'Connell P. et al. [87] \\
\hline 85-gene renal tissue signature & Associated with IFTA & Li L. et al. [156] \\
\hline Urinary mi-R21 and mi-R200b & $\begin{array}{l}\text { Increased expression predicts } \\
\text { IFTA and CAD }\end{array}$ & Zununi V. et al. [157] \\
\hline $\begin{array}{l}\text { Plasmatic miR-150, miR-192, miR-200b, } \\
\text { and miR-423-3p }\end{array}$ & $\begin{array}{l}\text { Highly accurate in identifying IFTA } \\
(\text { AUC }=0.87 ; \text { sensitivity }=78 \% ; \\
\text { specificity }=91 \%)\end{array}$ & Zununi V. et al. [158] \\
\hline $\begin{array}{l}\text { Plasmatic miR-21, miR-142-3p, } \\
\text { miR-155, and mi-R } 21\end{array}$ & $\begin{array}{l}\text { Upregulated in IFTA; } \\
\text { mi-R } 21 \text { correlates with GFR }\end{array}$ & Zununi V. et al. [159] \\
\hline miR-145-5p expression in blood cells & $\begin{array}{c}\text { Downregulated in IFTA; } \\
\text { It can discriminate it from acute and } \\
\text { borderline rejection }\end{array}$ & Matz M. et al. [160] \\
\hline
\end{tabular}

\subsubsection{Transcriptomic Studies}

Growing evidence of highly shared deregulated gene pathways between IFTA and AR suggests a common immunological etiology in most cases of late CAD [154].

Recent studies have focused on upregulation of genes involved in IFTA. Inflammation in IFTA areas ("inflammatory IFTA", i-IFTA) has been identified as pivotal element in prompting development of chronic renal damage, further underlying the relationship between chronic, subclinical immunological activity and irreversible fibrosis $[161,162]$.

Several transcriptomic studies have shed light on specific genes and miRNAs involved in fibrotic evolution of chronic rejection.

In a study by Mas V. et al. an upregulation of genes related to fibrosis (TGF $\beta$ ), extracellular matrix deposition, and immune response was found [155].

In the already quoted CTOT-04 trial, Lee J. R. et al. identified a four-gene urinary signature (mRNA for vimentin, NKCC2, E-cadherin, and 18S rRNA) which predicted IFTA [86].

In the study of Genomics of Chronic Allograft Rejection (GoCAR), renal biopsy transcriptome expression analysis identified a set of 13 genes which independently predicted development of CAD at the 12th month, despite normal histology at the 3rd month after KTx, in more than 200 prospectively followed patients with stable graft function. This multicenter study was validated in two independent 
cohorts and first raised hope that allograft injury may be detected before it becomes clinically evident [87].

Halloran et al. employed the "molecular microscope" approach (already discussed in the paragraph on AR) and demonstrated a progressively higher prevalence of IFTA lesions over time and its association with transcripts related to rejection and glomerulonephritis in late biopsies. This suggests a continuing, active tissue response rather than autonomous fibrogenesis and that early abrogation of the immunological process may be critical to block this evolution and preserve long-term graft function $[93,161]$.

Another transcriptomic study employed an 85-gene signature related to IFTA and employed it to test targeted new anti-fibrotic drugs [156].

\subsection{2. miRNAs}

miRNAs, which we already analyzed as candidate biomarkers in the setting of DGF and AR, are also opening new perspectives in this setting. Recent studies have proposed sets of urinary and renal biopsy miRNAs as prognostic biomarkers of IFTA and CAD [163].

Aberrant urinary mi-R21 and miR200b expression was associated with IFTA and CAD [157].

Plasma circulating levels of miR-150, miR-192, miR-200b, and miR-423-3p were significantly different between patients with IFTA and those with stable renal Tx and accurately identified IFTA $($ AUC $=0.87 ;$ sensitivity $=78 \%$; specificity $=91 \%)[158]$.

In another study, plasma expression of miR-21, miR-142-3p, and miR-155 were upregulated in IFTA and mi-R 21 levels were positively correlated with eGFR [159].

On the contrary, miR-145-5p expression in blood cells was significantly downregulated in IFTA and could discriminate it from many other active lesions, such as TCMR, ABMR, borderline-rejection, and from a condition of stable graft function [160].

Another area of active research is that of epigenetic modifications of immunity genes on progression to IFTA: epigenetic mechanisms such as hypomethylation could directly enhance their expression and also indirectly modulate it by regulating miRNAs [164].

\subsubsection{Biomarkers of EMT and EndMT}

IF is determined by massive deposition of EM, which is mainly produced by activated myofibroblasts probably derived from several cell types, especially renal tubular cells, through EMT.

This process, promoted by several factors such as oxidative stress and mitochondrial dysfunction due to IRI, deeply alters epithelial cell properties, determining loss of polarity and cell-cell adhesion and assumption of a mesenchymal phenotype, characterized by markedly increased production of EM [165].

More recently, activated myofibroblasts have been shown to arise also from renal endothelial cells through a similar process, EndMT, already mentioned in the section on DGF [166].

Both EMT and EndMT lead to abnormal production of EM and consequently play a key role in the pathogenesis of allograft IFTA [161]. Several histological and urinary EMT biomarkers have been proposed (Table 8), whereas more recent, initial evidence on potential EndMT biomarkers in KTx is available. Biomarkers of both processes will be analyzed. 
Table 8. Potential biomarkers for epithelial-to-mesenchymal transition (EMT).

\begin{tabular}{ccc}
\hline Biomarker & Main Features & Author \\
\hline CD45, VIM, and POSTN & $\begin{array}{c}\text { They correlate to each other and with } \\
\text { iIFTA and graft loss }\end{array}$ & Alfieri C et al. [167] \\
\hline Smurf 1 & $\begin{array}{c}\text { It is included in a pathway involved in } \\
\text { EMT. Its inhibition by Bortezomib may } \\
\text { mediate its anti-fibrotic effect. }\end{array}$ & Zhou J et al. [168] \\
\hline VIM and $\beta$-catenin & $\begin{array}{c}\text { Tubular expression correlates with IFTA } \\
\text { and long-term eGFR decline }\end{array}$ & Hazzan M et al. [169] \\
\hline Senescence biomarkers (e.g., p16INK4a) & $\begin{array}{c}\text { They mark SASP, an inflammatory } \\
\text { phenotype connected to EMT }\end{array}$ & Sosa Pena DPM et al. [170]. \\
\hline VIM and CD45 & $\begin{array}{c}\text { This ratio based on urinary mRNAs } \\
\text { correlates with VIM expression in renal } \\
\text { tissue and may detect EMT and early } \\
\text { graft fibrogenesis }\end{array}$ & Mezni I et al. [171] \\
\hline Urinary transcriptomic patterns & $\begin{array}{c}\text { They are associated with pEMT and } \\
\text { subclinical graft injury }\end{array}$ & Galichon P et al. [172] \\
\hline
\end{tabular}

\section{(a) Biomarkers of EMT}

\section{Histological biomarkers}

In a recent study, renal expression of CD45, vimentin (VIM), and periostin (POSTN) correlated with iIFTA and POSTN was the strongest predictor of graft loss. Of interest, its expression was inversely correlated with 25(OH)VitD levels, suggesting that these might influence graft fibrosis [167].

Smad ubiquitination regulatory factor 1 (Smurf1) is part of Smurf1/Akt/mTOR/P70S6K signaling pathway, activated by TNF- $\alpha$ and involved in EMT. Of interest, Bortezomib blunted progression of EMT and IF by inhibiting TNF- $\alpha$ production and consequently expression of Smurf1, suggesting that this could be an EMT biomarker with diagnostic and therapeutic value [168].

Tubular expression of VIM and $\beta$-catenin, biomarkers of EMT, in protocol biopsy performed 3 months after KTx, was an independent risk factor for IFTA and eGFR decline up to 4 years post-transplant in CsA-treated recipients [169].

Finally, an interesting area of research is that of cellular senescence. This is associated with an inflammatory, "senescence-associated secretory phenotype" (SASP) which is tightly connected to EMT and CAD. Senescence markers (e.g., p16 ${ }^{\mathrm{INK} 4 \mathrm{a}}$ ) could therefore be considered as potential surrogate biomarkers of EMT [170].

\section{Urinary biomarkers}

An interesting non-invasive biomarker of EMT is the ratio between VIM and CD45 relative to uroplakin 1a (UPK) urinary mRNA, which has been shown to correlate with intensity of VIM renal expression measured with immunostaining in per-protocol renal biopsies [171].

Other studies adopting a whole transcriptomic analysis approach identified specific urinary transcriptomic patterns associated with pEMT. Unbiased pathway analysis revealed that these patterns expressed increased inflammation and reduced metabolic functions, suggesting that they may be effective to detect subclinical immune response leading to EMT and graft fibrosis [172].

\section{(b) Biomarkers of EndMT}

Three biomarkers of EndMT, fascin1, vimentin, and heat shock protein 47, were strongly expressed in endothelial cells of peritubular capillaries in ABMR as compared to stable patients and predicted late graft dysfunction (up to 4 years since ABMR diagnosis) better than histological lesions. These results suggest that they may be reliable in identifying persistent endothelial activation and evolution towards cABMR [173]. 
In vitro and in vivo experimental studies demonstrated that EndMT may promote IF by targeting the TGF- $\beta /$ Smad and Akt/mTOR/p70S6K signaling pathways, indicating that components of these pathways may be a potential source of EndMT biomarkers [174].

Finally, E Glover et al. analyzed evidence of miRNAs regulation of EndMT from experimental studies and their potential impact on kidney and other solid organ allograft dysfunction in a recent review. However, clinical studies in humans are needed to confirm their role as EndMT biomarkers [175].

\subsection{Chronic CNI Nephrotoxicity}

Some other studies identified potential specific biomarkers for chronic CNI nephrotoxicity, which are outlined in Table 9.

Chronic ischemia due to the vasoconstrictive effect of CNI triggers an alteration in expression of proteins involved in pro-inflammatory response and oxidative stress; however, the renal histology of chronic CNI nephrotoxicity is not peculiar (it may in fact merely determine IFTA) and this hampers efforts to identify specific biomarkers [176].

A metabolomic study compared urine from healthy subjects and KTx recipients with biopsy-proven chronic TAC nephrotoxicity and proposed symmetric dimethylarginine and serine as marker of this type of kidney injury (ROC analysis AUC of 0.95 and 0.81, respectively) [177].

uNGAL was proved to correlate with duration of CsA therapy in children with CNI nephrotoxicity [178].

A SNP in the FK-506-binding protein (FKBP), rs6041749 C variant, appeared to enhance FKBP1A gene transcription compared to the $\mathrm{T}$ variant and was associated with an increased risk of CAD in a Chinese cohort of TAC-treated KTx recipients, although with an unclear mechanism [179].

Other studies in rat models have reported increased urinary levels of TNA $\alpha$, LIM-1, and FN in the early phase of CsA nephrotoxicity and late increases of urinary Osteopontin and TGF- $\beta$ in chronic nephrotoxicity [180].

Decreased expression of Slc12a3 and KS-WNK1, leading to impaired sodium transport in distal tubules and chronic activation of renin-angiotensin system, was associated with CsA and TAC nephrotoxicity in another rat model [181]. Potential biomarkers identified in the last two experimental studies need to be validated in humans.

Table 9. Potential biomarkers for chronic calcineurin-inhibitor (CNI) nephrotoxicity.

\begin{tabular}{ccc}
\hline Biomarker & Main Features & Author \\
\hline $\begin{array}{c}\text { Urinary symmetric } \\
\text { dimethylarginine and serine }\end{array}$ & $\begin{array}{c}\text { Highly accurate for CNI nephrotoxicity } \\
\text { (AUC of 0.95 and 0.81, respectively) }\end{array}$ & Xia T et al. [177] \\
\hline uNGAL & $\begin{array}{c}\text { It correlates with duration of CsA therapy } \\
\text { in children with CNI nephrotoxicity }\end{array}$ & Gacka E et al. [178] \\
\hline $\begin{array}{c}\text { Genetic polymorphism of } \\
\text { FK-506-binding protein, } \\
\text { rs6041749 C variant }\end{array}$ & $\begin{array}{c}\text { It enhances FKBP1A gene transcription } \\
\text { and is associated with an increased risk of } \\
\text { CAD in TAC-treated KTx recipients }\end{array}$ & Wu Z et al. [179] \\
\hline $\begin{array}{c}\text { Increased urinary TNA } \alpha, \\
\text { LIM-1, FN Osteopontin, and } \\
\text { TGF- } \beta\end{array}$ & $\begin{array}{c}\text { These markers correlate with different } \\
\text { stages of CsA nephrotoxicity in rat models }\end{array}$ & Carlos C et al. [180] \\
\hline $\begin{array}{c}\text { Decreased renal expression of } \\
\text { Slc12a3 and } \\
\text { KS-WNK1 }\end{array}$ & $\begin{array}{c}\text { These markers correlate with different } \\
\text { stages of CNI nephrotoxicity in rat models }\end{array}$ & Cui Y et al. [181] \\
\hline
\end{tabular}

\subsection{PVAN}

Potential biomarkers for PVAN, an important cause of CAD [182], are outlined in Table 10. 
Table 10. Potential biomarkers for Polyomavirus-associated nephropathy (PVAN).

\begin{tabular}{ccc}
\hline Biomarker & Main Features & Author \\
\hline $\begin{array}{c}\text { Urinary exosomal bkv-miR-B1-5p } \\
\text { and bkv-miR-B1-5p/miR-16 }\end{array}$ & Excellent diagnostic accuracy for PVAN & Kim M et al. [183] \\
\hline Urinary CXCL10 & $\begin{array}{c}\text { Associated with subclinical } \\
\text { tubule-interstitial inflammation and viremia }\end{array}$ & Ho J et al. [184] \\
\hline IL28B SNP C/T (rs12979860) & $\begin{array}{c}\text { Associated with presence of PVAN in } \\
\text { viremic patients }\end{array}$ & Dvir R et al. [185] \\
\hline
\end{tabular}

Urinary exosomal bkv-miR-B1-5p and bkv-miR-B1-5p/miR-16, two miRNAs encoded by PVAN, have both demonstrated very high discriminative capacity for this complication (ROC AUC 0.98 for each) as compared with that of commonly used surrogate biomarkers, such as plasma viral load [183].

Urinary CXCL10 has been associated with subclinical inflammation within the tubule-interstitial and peritubular capillary spaces and correlated with Polyomavirus viremia [184].

A single nucleotide polymorphism (SNP) of IL28B (C/T polymorphism rs12979860) was associated with presence of PVAN, discriminating these patients from those with viremia without any renal involvement [185].

The search for renal tissue transcriptomic biomarkers of PVAN has not provided any solid result so far. Overlap in pathogenetic mechanisms and gene expression between PVAN and non-viral forms of allograft injury, such as TCMR and iIFTA, makes it difficult to identify peculiar molecular signatures [186].

\section{Current Limits and Perspectives of Biomarkers in Renal Transplant}

Advances in high-throughput technologies have been providing an avalanche of new potential biomarkers over the last decade. However, in general, their application in clinical practice is currently being restrained by several drawbacks. Most available biomarkers do not meet ideal requirements outlined in Table 11 and certainly require further validation through multicenter studies, as single-center discovery step often inflates their value [187].

Most important, their role and cost-effectiveness should be assessed in prospective randomized trials designed to compare them with standard KTx management with traditional diagnostic tools.

Despite these limits, biomarkers represent the cornerstone of precision medicine, which aims at integrating traditional clinical information and tailoring medical care to select the best treatment for an individual patient [5]. This new frontier will probably deeply change the way we monitor KTx and manage its complications.

Renal biopsy, the traditional gold standard for assessing graft dysfunction, is usually triggered by a change in serum creatinine and/or proteinuria and has a limited diagnostic power for initial injury, when histological changes are minimal or equivocal [3]. By contrast, an ideal biomarker (or a set of biomarkers) should lead to an earlier and more objective diagnosis (Table 11) making it possible to pre-emptively treat histological initial lesions long before they become irreversible, or even before they become visible with traditional tools, marking patterns of molecular alterations which predate histological injury ("molecular rejection"). Biomarkers could decrease the need for renal biopsy to detect subclinical disease (e.g., protocol biopsies) and even substitute for it when contraindicated. Furthermore, while current new potential biomarkers in KTx mainly have a diagnostic/prognostic meaning, the area of monitoring, pharmacodynamic/response, and safety biomarkers (Table 1) is substantially unexplored in this setting and could help us improve long-term management of allograft dysfunction (e.g., follow-up of patients after BPAR, with repeated, non-invasive monitoring biomarkers to rule out persistence of ongoing subclinical rejection; assessment of etiology and degree of activity/chronicity in CAD). 
Table 11. Features of an ideal biomarker for kidney transplant (KTx) $[1,2,187]$.

\begin{tabular}{|c|c|}
\hline Biomarker Features & Comment \\
\hline Non-invasive and easy to measure & $\begin{array}{l}\text { Urine and blood biomarkers are easily available and can be } \\
\text { serially measured, whereas renal tissue biomarkers require renal } \\
\text { biopsy with inherent invasiveness and limits. Urine and blood } \\
\text { biomarkers may be used when renal biopsy is contraindicated or } \\
\text { reduce the need for repeated surveillance biopsies. }\end{array}$ \\
\hline Short turn-around time & $\begin{array}{l}\text { Results should be available within a time frame which allows } \\
\text { rapid, potentially pre-emptive intervention (e.g., diagnosis of } \\
\text { subclinical AR) }\end{array}$ \\
\hline Easy to interpret & $\begin{array}{l}\text { Results should be easy to interpret, and threshold values should } \\
\text { be established to help transplant physician in clinical practice }\end{array}$ \\
\hline Reproducible and standardized & $\begin{array}{l}\text { Results should be validated in multiple independent cohorts with } \\
\text { different features (e.g., elderly, or highly sensitized KTx recipients, } \\
\text { or different ethnicity) and assay standardization of analytical } \\
\text { process performed in order to minimize inter-laboratory and } \\
\text { inter-platform variability }\end{array}$ \\
\hline Accuracy (sensitivity and specificity) & $\begin{array}{l}\text { Biomarker levels should strictly reflect a single specific } \\
\text { pathological process, without being influenced by other causes of } \\
\text { kidney damage (e.g., AR vs. CNI nephrotoxicity or vs. infections) }\end{array}$ \\
\hline Good prognostic performance (PPV and NPV) & $\begin{array}{l}\text { Acceptable PPP and NPP. In general, new biomarkers should be } \\
\text { preferably tested in subsets of patients at different immunological } \\
\text { risk, rather than on the transplant population as a whole, in order } \\
\text { to improve their statistical performance (e.g., higher a priori } \\
\text { chance of AR in highly sensitized KTx recipients improves PPV } \\
\text { compared to standard recipients). }\end{array}$ \\
\hline Proof of cause & $\begin{array}{l}\text { Reduction of a biomarker level correlates with an improvement in } \\
\text { the underlying pathological process assessed with current } \\
\text { gold-standard (histological examination with renal biopsy) }\end{array}$ \\
\hline Cost-effective & $\begin{array}{l}\text { Results should improve clinical management and consequently } \\
\text { impact long-term outcomes and related economic aspects, } \\
\text { justifying biomarker costs (e.g., a biomarker which detects } \\
\text { subclinical AR could improve treatment, prolong graft survival } \\
\text { and reduce costs) }\end{array}$ \\
\hline
\end{tabular}

Particularly interesting perspectives are immunological risk stratification and identification of low-risk, or even tolerant patients.

Peripheral blood gene expression tests such TruGraf [91] or kSORT [57] have already become commercial and appear accurate in identifying a state of "immunological quiescence" in stable recipients; due to their high NPP they could allow to rule out ongoing subclinical rejection through serial monitoring, as an alternative to surveillance biopsies, and guide immunosuppression minimization in fragile patients at low immunological risk [188].

A further step forward would be to identify biomarkers of operational tolerance, a rare condition characterized by maintenance of stable renal function without any immunosuppressive therapy.

Tolerant patients seem to be depicted by increased expression of $B$ cell associated genes in the blood and urine and by a peculiar B cell repertoire, enriched in naive and transitional B cells. Of interest, this pattern appears to be associated with better long-term graft function [189] and potential biomarkers of this process are beginning to emerge. For example, TCL1A, an oncogene expressed in immature naive and transitional B cells, and promoting their survival, has been associated with immunosuppressive properties of this lymphocyte sub-population and seems to be upregulated in stable, rejection-free KTx recipients [190].

Of interest, Newell et al. identified a B-cell signature formed by a set of three genes which correlated with increased expression of CD20 mRNAs (FoxP3, CD20, CD3, perforin) in urinary sediment of tolerant patients compared to healthy controls (all of them) and to stable KTx (only CD20) [191], whereas Danger et al. showed that a composite score based on a 20-gene signature peripheral blood cells could accurately discriminate operationally tolerant recipients from stable ones, independent 
of immunosuppressive therapy [192]. All these approaches need to be validated, but they may pave the way for the identification of tolerance biomarkers, with important implications on management of immunosuppressive therapy [193]. The state-of-the-art of this family of biomarkers was recently analyzed in several reviews $[2,194,195]$ and is beyond the scope of this work.

At the other end of the spectrum, biomarkers could be preferably employed to monitor high-immunological risk patients (e.g., sensitized, DSA-positive recipients). Testing biomarkers in this subset helps increase PPP due to a higher a priori risk of AR. A combination of different biomarkers can also increase diagnostic accuracy; for example, association of kSORT with IFN $\gamma$ ELISPOT improves predictive power for subclinical TCMR and ABMR [74].

Another intriguing perspective is the application of artificial intelligence (AI) models which allows computational analysis and interpretation of large-scale molecular data generation by exploiting machine learning algorithms and neural networks [196,197]. For example, classifiers like artificial neural networks, support vector machines and Bayesian inference have already been employed in pilot studies to screen KTx recipients requiring renal biopsy [198] and AI has proved useful to improve estimation of TAC Area Under the Concentration Over Time Curve [199].

"Molecular microscope" is another important example application of AI to renal tissue transcriptomic analysis $[93,94]$.

In another recent work an unsupervised learning method integrating a wide range of parameters (clinical functional, immunologic, and histologic) was applied to a large cohort of KTx recipients and allowed to classify five transplant glomerulopathy archetypes, each associated with a different allograft 5-year graft survival (ranging from $88 \%$ to $22 \%$ ) [200].

These studies suggest that progress in AI can significantly contribute to a completely new, more accurate disease nosology, integrating complex sets of biomarkers of different nature (from clinical data to molecular aspects) for a subtle characterization of traditional entities.

\section{Conclusions}

Development of Omics technology and expanding knowledge of new tools, such as EVs and dd-cfDNA, has led to an increased availability of a wide range of new potential biomarkers, which may be applied to all key settings of early and late graft dysfunction. Non-invasive biomarkers measured in urine or blood appear promising in providing very early diagnosis of pathological processes, such as subclinical AR, or in stratifying risk of DGF or of rejection, potentially reducing need for surveillance biopsies to monitor low-risk recipients. Tissue biomarkers have also proved effective in integrating traditional histology, leading to improved disease nosology and more accurate prognosis. Tolerance biomarkers and progress in AI are opening new frontiers, which may revolutionize transplant medicine.

Although larger, multi-center validation studies are needed before combination of biomarkers can be widely implemented in the clinic, the transplant physician should rise to the challenge of becoming familiar with this new landscape, in order to start taking advantage of the various facets of its huge potential.

Author Contributions: M.Q. and V.C. designed and wrote the initial manuscript; G.M. designed Figure and Tables; G.G. organized References; G.C. contributed to specific parts concerning Complement-related biomarkers. All authors critically revised, discussed and edited the article until it reached its current form and agreed to the published version of the manuscript. All authors have read and agreed to the published version of the manuscript.

Funding: This study was (partially) funded by the Italian Ministry of Education, University and Research (MIUR) program "Departments of Excellence 2018-2022", AGING Project-Department of Translational Medicine, University of Piemonte Orientale (UPO) and by local grants of the University of Piemonte Orientale (UPO, FAR) to M.Q. and V.C.

Conflicts of Interest: The authors declare no conflict of interest. 


\section{Abbreviations}

\begin{tabular}{|c|c|}
\hline ABMR & antibody-mediated rejection \\
\hline cABMR & chronic antibody-mediated rejection \\
\hline AI & artificial intelligence \\
\hline $\mathrm{AR}$ & acute rejection \\
\hline ATN & acute tubular necrosis \\
\hline AT1R & Angiotensin 2 receptor 1 \\
\hline AUC & area under the curve \\
\hline CAD & chronic allograft dysfunction \\
\hline $\mathrm{CNI}$ & calcineurin inhibitor \\
\hline Col-IV & Collagen type IV \\
\hline CsA & Cyclosporin A \\
\hline DCD & donation after circulatory death \\
\hline DBD & donation after brain death \\
\hline DGF & delayed graft function \\
\hline DSA & donor-specific antibodies \\
\hline ECD & extended criteria donor \\
\hline EDIL-3 & EGF-like repeats and discoidin I-like domains 3 \\
\hline EM & extracellular matrix \\
\hline EMT & epithelial-to-mesenchymal transition \\
\hline ENDATs & endothelial associated transcripts \\
\hline EndMT & endothelial-to-mesenchymal transition \\
\hline ETAR & endothelin type A receptor \\
\hline EVs & extracellular vesicles \\
\hline FLT3-L & Fms-like tyrosine kinase-3 ligand \\
\hline $\mathrm{FN}$ & Fibronectin \\
\hline GFR & glomerular filtration rate \\
\hline GST & glutathione S-transferase \\
\hline HLA & human leukocyte antigen \\
\hline HSP & heat shock protein \\
\hline ICAM-4 & intercellular adhesion molecule 4 \\
\hline IFTA & interstitial fibrosis tubular atrophy \\
\hline iIFTA & inflammatory interstitial fibrosis tubular atrophy \\
\hline IRI & ischemia-reperfusion injury \\
\hline kSORT & kidney solid organ response test \\
\hline KTx & kidney transplant \\
\hline KTR-3 & Keratin-3 \\
\hline FST & furosemide stress test \\
\hline LD & living-donor \\
\hline MFI & mean fluorescence intensity \\
\hline MMP-2 & matrix metalloprotein-2 \\
\hline miRNA & microRNA \\
\hline NGAL & neutrophil gelatinase-associated lipocalin \\
\hline NPP & negative predictive power \\
\hline PBTs & pathogenesis-based transcript sets \\
\hline pEMT & partial epithelial-to-mesenchymal transition \\
\hline POSTN & Periostin \\
\hline PVAN & Polyomavirus-associated nephropathy \\
\hline PPP & Positive predictive power \\
\hline ROC & receiver operating characteristic \\
\hline SNP & single nucleotide polymorphism \\
\hline TAC & Tacrolimus \\
\hline TCMR & T-cell mediated rejection \\
\hline tCRM & tissue common rejection module \\
\hline TIMP-2 & tissue inhibitor of metalloproteinases- 2 \\
\hline TLR-4 & Toll-like receptor 4 \\
\hline VIM & Vimentin \\
\hline
\end{tabular}




\section{References}

1. Califf, R.M. Biomarker definitions and their applications. Exp. Biol. Med. Maywood NJ 2018, 243, $213-221$. [CrossRef] [PubMed]

2. Salvadori, M.; Tsalouchos, A. Biomarkers in renal transplantation: An updated review. World J. Transplant. 2017, 7, 161-178. [CrossRef] [PubMed]

3. Sarwal, M.; Chua, M.-S.; Kambham, N.; Hsieh, S.-C.; Satterwhite, T.; Masek, M.; Salvatierra, O.J. Molecular heterogeneity in acute renal allograft rejection identified by DNA microarray profiling. N. Engl. J. Med. 2003, 349, 125-138. [CrossRef]

4. Stapleton, C.P.; Conlon, P.J.; Phelan, P.J. Using omics to explore complications of kidney transplantation. Transpl. Int. 2018, 31, 251-262. [CrossRef] [PubMed]

5. Naesens, M.; Anglicheau, D. Precision Transplant Medicine: Biomarkers to the Rescue. J. Am. Soc. Nephrol. 2018, 29, 24-34. [CrossRef] [PubMed]

6. Herath, S.; Erlich, J.; Au, A.Y.M.; Endre, Z.H. Advances in Detection of Kidney Transplant Injury. Mol. Diagn. Ther. 2019, 23, 333-351. [CrossRef] [PubMed]

7. Nashan, B.; Abbud-Filho, M.; Citterio, F. Prediction, prevention, and management of delayed graft function: Where are we now? Clin. Transplant. 2016, 30, 1198-1208. [CrossRef]

8. Noble, J.; Jouve, T.; Malvezzi, P.; Süsal, C.; Rostaing, L. Transplantation of Marginal Organs: Immunological Aspects and Therapeutic Perspectives in Kidney Transplantation. Front. Immunol. 2019, 10, 3142. [CrossRef]

9. Caulfield, T.; Murdoch, B.; Sapir-Pichhadze, R.; Keown, P. Policy Challenges for Organ Allocation in an Era of "Precision Medicine". Can. J. Kidney Health Dis. 2020, 7, 2054358120912655. [CrossRef]

10. Han, F.; Wan, S.; Sun, Q.; Chen, N.; Li, H.; Zheng, L.; Zhang, N.; Huang, Z.; Hong, L.; Sun, Q. Donor Plasma Mitochondrial DNA Is Correlated with Posttransplant Renal Allograft Function. Transplantation 2019, 103, 2347-2358. [CrossRef]

11. Schröppel, B.; Heeger, P.S.; Thiessen-Philbrook, H.; Hall, I.E.; Doshi, M.D.; Weng, F.L.; Reese, P.P.; Parikh, C.R. Donor Urinary C5a Levels Independently Correlate with Posttransplant Delayed Graft Function. Transplantation 2019, 103, e29-e35. [CrossRef] [PubMed]

12. Gómez-Dos-Santos, V.; Ramos-Muñoz, E.; García-Bermejo, M.L.; Ruiz-Hernández, M.; Rodríguez-Serrano, E.M.; Saiz-González, A.; Martínez-Perez, A.; Burgos-Revilla, F.J. MicroRNAs in Kidney Machine Perfusion Fluid as Novel Biomarkers for Graft Function. Normalization Methods for miRNAs Profile Analysis. Transplant. Proc. 2019, 51, 307-310. [CrossRef] [PubMed]

13. Roest, H.P.; Ooms, L.S.S.; Gillis, A.J.M.; IJzermans, J.N.M.; Looijenga, L.H.J.; Dorssers, L.C.J.; Dor, F.J.M.F.; van der Laan, L.J.W. Cell-free MicroRNA miR-505-3p in Graft Preservation Fluid Is an Independent Predictor of Delayed Graft Function After Kidney Transplantation. Transplantation 2019, 103, 329-335. [CrossRef] [PubMed]

14. Moser, M.A.J.; Sawicka, K.; Arcand, S.; O’Brien, P.; Luke, P.; Beck, G.; Sawicka, J.; Cohen, A.; Sawicki, G. Proteomic Analysis of Perfusate from Machine Cold Perfusion of Transplant Kidneys: Insights into Protection from Injury. Ann. Transplant. 2017, 22, 730-739. [CrossRef] [PubMed]

15. Cappuccilli, M.; Capelli, I.; Comai, G.; Cianciolo, G.; La Manna, G. Neutrophil Gelatinase-Associated Lipocalin as a Biomarker of Allograft Function after Renal Transplantation: Evaluation of the Current Status and Future Insights. Artif. Organs 2018, 42, 8-14. [CrossRef]

16. Hall, I.E.; Bhangoo, R.S.; Reese, P.P.; Doshi, M.D.; Weng, F.L.; Hong, K.; Lin, H.; Han, G.; Hasz, R.D.; Goldstein, M.J.; et al. Glutathione S-transferase iso-enzymes in perfusate from pumped kidneys are associated with delayed graft function. Am. J. Transplant. 2014, 14, 886-896. [CrossRef]

17. Udomkarnjananun, S.; Townamchai, N.; Iampenkhae, K.; Petchlorlian, A.; Srisawat, N.; Katavetin, P.; Sutherasan, M.; Santingamkun, A.; Praditpornsilpa, K.; Eiam-Ong, S.; et al. Furosemide Stress Test as a Predicting Biomarker for Delayed Graft Function in Kidney Transplantation. Nephron 2019, 141, $236-248$. [CrossRef]

18. Wilflingseder, J.; Sunzenauer, J.; Toronyi, E.; Heinzel, A.; Kainz, A.; Mayer, B.; Perco, P.; Telkes, G.; Langer, R.M.; Oberbauer, R. Molecular pathogenesis of post-transplant acute kidney injury: Assessment of whole-genome mRNA and miRNA profiles. PLoS ONE 2014, 9, e104164. [CrossRef]

19. Milhoransa, P.; Montanari, C.C.; Montenegro, R.; Manfro, R.C. Micro RNA 146a-5p expression in Kidney transplant recipients with delayed graft function. Braz. J. Nephrol. 2019, 41, 242-251. [CrossRef] 
20. Khalid, U.; Newbury, L.J.; Simpson, K.; Jenkins, R.H.; Bowen, T.; Bates, L.; Sheerin, N.S.; Chavez, R.; Fraser, D.J. A urinary microRNA panel that is an early predictive biomarker of delayed graft function following kidney transplantation. Sci. Rep. 2019, 9, 3584. [CrossRef]

21. Maier, H.T.; Ashraf, M.I.; Denecke, C.; Weiss, S.; Augustin, F.; Messner, F.; Vallant, N.; Böcklein, M.; Margreiter, C.; Göbel, G.; et al. Prediction of delayed graft function and long-term graft survival by serum and urinary neutrophil gelatinase-associated lipocalin during the early postoperative phase after kidney transplantation. PLoS ONE 2018, 13, e0189932. [CrossRef] [PubMed]

22. Ramirez-Sandoval, J.C.; Herrington, W.; Morales-Buenrostro, L.E. Neutrophil gelatinase-associated lipocalin in kidney transplantation: A review. Transplant. Rev. 2015, 29, 139-144. [CrossRef] [PubMed]

23. Li, Y.M.; Li, Y.; Yan, L.; Wang, H.; Wu, X.J.; Tang, J.T.; Wang, L.L.; Shi, Y.Y. Comparison of urine and blood NGAL for early prediction of delayed graft function in adult kidney transplant recipients: A meta-analysis of observational studies. BMC Nephrol. 2019, 20, 291. [CrossRef] [PubMed]

24. Sahraei, Z.; Mehdizadeh, M.; Salamzadeh, J.; Nafar, M.; Eshraghi, A. Association between Delayed Graft Function (DGF) Biomarkers and Long-term Outcomes after Living Donor Kidney Transplantation. Rev. Recent Clin. Trials 2018, 13, 312-318. [CrossRef]

25. Hu, X.; Su, M.; Lin, J.; Zhang, L.; Sun, W.; Zhang, J.; Tian, Y.; Qiu, W. Corin Is Downregulated in Renal Ischemia/Reperfusion Injury and Is Associated with Delayed Graft Function after Kidney Transplantation. Dis. Markers 2019, 2019, 9429323. [CrossRef]

26. Zmonarski, S.; Madziarska, K.; Banasik, M.; Mazanowska, O.; Magott-Procelewska, M.; Hap, K.; Krajewska, M. Expression of PBMC TLR4 in Renal Graft Recipients Who Experienced Delayed Graft Function Reflects Dynamic Balance Between Blood and Tissue Compartments and Helps Select a Problematic Patient. Transplant. Proc. 2018, 50, 1744-1749. [CrossRef]

27. Comai, G.; Baraldi, O.; Cuna, V.; Corradetti, V.; Angeletti, A.; Brunilda, S.; Capelli, I.; Cappuccilli, M.; LA Manna, G. Increase in Serum Amylase and Resistive Index after Kidney Transplant Are Biomarkers of Delayed Graft Function. Vivo Athens Greece 2018, 32, 397-402. [CrossRef]

28. Xu-Dubois, Y.-C.; Ahmadpoor, P.; Brocheriou, I.; Louis, K.; Snanoudj, N.A.; Rouvier, P.; Taupin, J.-L.; Corchia, A.; Galichon, P.; Barrou, B.; et al. Microvasculature partial endothelial mesenchymal transition in early posttransplant biopsy with acute tubular necrosis identifies poor recovery renal allografts. Am. J. Transplant. 2020. [CrossRef]

29. Castellano, G.; Franzin, R.; Stasi, A.; Divella, C.; Sallustio, F.; Pontrelli, P.; Lucarelli, G.; Battaglia, M.; Staffieri, F.; Crovace, A.; et al. Complement Activation during Ischemia/Reperfusion Injury Induces Pericyte-to-Myofibroblast Transdifferentiation Regulating Peritubular Capillary Lumen Reduction Through pERK Signaling. Front. Immunol. 2018, 9, 1002. [CrossRef]

30. Castellano, G.; Franzin, R.; Sallustio, F.; Stasi, A.; Banelli, B.; Romani, M.; De Palma, G.; Lucarelli, G.; Divella, C.; Battaglia, M.; et al. Complement component C5a induces aberrant epigenetic modifications in renal tubular epithelial cells accelerating senescence by Wnt4/ßcatenin signaling after ischemia/reperfusion injury. Aging 2019, 11, 4382-4406. [CrossRef]

31. Curci, C.; Castellano, G.; Stasi, A.; Divella, C.; Loverre, A.; Gigante, M.; Simone, S.; Cariello, M.; Montinaro, V.; Lucarelli, G.; et al. Endothelial-to-mesenchymal transition and renal fibrosis in ischaemia/reperfusion injury are mediated by complement anaphylatoxins and Akt pathway. Nephrol. Dial. Transplant. 2014, 29, 799-808. [CrossRef] [PubMed]

32. Lu, T.X.; Rothenberg, M.E. MicroRNA. J. Allergy Clin. Immunol. 2018, 141, 1202-1207. [CrossRef] [PubMed]

33. Gremmels, H.; de Jong, O.G.; Toorop, R.J.; Michielsen, L.; van Zuilen, A.D.; Vlassov, A.V.; Verhaar, M.C.; van Balkom, B.W.M. The Small RNA Repertoire of Small Extracellular Vesicles Isolated from Donor Kidney Preservation Fluid Provides a Source for Biomarker Discovery for Organ Quality and Posttransplantation Graft Function. Transplant. Direct 2019, 5, e484. [CrossRef] [PubMed]

34. Franco-Acevedo, A.; Melo, Z.; Echavarria, R. Diagnostic, Prognostic, and Therapeutic Value of Non-Coding RNA Expression Profiles in Renal Transplantation. Diagnostics 2020, 10, 60. [CrossRef] [PubMed]

35. Wilflingseder, J.; Reindl-Schwaighofer, R.; Sunzenauer, J.; Kainz, A.; Heinzel, A.; Mayer, B.; Oberbauer, R. MicroRNAs in kidney transplantation. Nephrol. Dial. Transplant. 2015, 30, 910-917. [CrossRef]

36. Trionfini, P.; Benigni, A.; Remuzzi, G. MicroRNAs in kidney physiology and disease. Nat. Rev. Nephrol. 2015, 11, 23-33. [CrossRef] 
37. Su, M.; Hu, X.; Lin, J.; Zhang, L.; Sun, W.; Zhang, J.; Tian, Y.; Qiu, W. Identification of Candidate Genes Involved in Renal Ischemia/Reperfusion Injury. DNA Cell Biol. 2019, 38, 256-262. [CrossRef]

38. Cantaluppi, V.; Dellepiane, S.; Tamagnone, M.; Medica, D.; Figliolini, F.; Messina, M.; Manzione, A.M.; Gai, M.; Tognarelli, G.; Ranghino, A.; et al. Neutrophil Gelatinase Associated Lipocalin Is an Early and Accurate Biomarker of Graft Function and Tissue Regeneration in Kidney Transplantation from Extended Criteria Donors. PLoS ONE 2015, 10, e0129279. [CrossRef]

39. Bank, J.R.; Ruhaak, R.; Soonawala, D.; Mayboroda, O.; Romijn, F.P.; van Kooten, C.; Cobbaert, C.M.; de Fijter, J.W. Urinary TIMP-2 Predicts the Presence and Duration of Delayed Graft Function in Donation after Circulatory Death Kidney Transplant Recipients. Transplantation 2019, 103, 1014-1023. [CrossRef]

40. Van Niel, G.; D'Angelo, G.; Raposo, G. Shedding light on the cell biology of extracellular vesicles. Nat. Rev. Mol. Cell Biol. 2018, 19, 213-228. [CrossRef]

41. Karpman, D.; Ståhl, A.-L.; Arvidsson, I. Extracellular vesicles in renal disease. Nat. Rev. Nephrol. 2017, 13, 545-562. [CrossRef] [PubMed]

42. Quaglia, M.; Dellepiane, S.; Guglielmetti, G.; Merlotti, G.; Castellano, G.; Cantaluppi, V. Extracellular Vesicles as Mediators of Cellular Crosstalk between Immune System and Kidney Graft. Front. Immunol. 2020, 11, 74. [CrossRef] [PubMed]

43. Dursun, I.; Yel, S.; Unsur, E. Dynamics of circulating microparticles in chronic kidney disease and transplantation: Is it really reliable marker? World J. Transplant. 2015, 5, 267-275. [CrossRef] [PubMed]

44. Al-Massarani, G.; Vacher-Coponat, H.; Paul, P.; Widemann, A.; Arnaud, L.; Loundou, A.; Robert, S.; Berland, Y.; Dignat-George, F.; Camoin-Jau, L. Impact of immunosuppressive treatment on endothelial biomarkers after kidney transplantation. Am. J. Transplant. 2008, 8, 2360-2367. [CrossRef]

45. Al-Massarani, G.; Vacher-Coponat, H.; Paul, P.; Arnaud, L.; Loundou, A.; Robert, S.; Moal, V.; Berland, Y.; Dignat-George, F.; Camoin-Jau, L. Kidney transplantation decreases the level and procoagulant activity of circulating microparticles. Am. J. Transplant. 2009, 9, 550-557. [CrossRef]

46. Martins, S.R.; Alves, L.V.; Cardoso, C.N.; Silva, L.G.; Nunes, F.F.; de Lucas Júnior, F.M.; Silva, A.C.; Dusse, L.M.; Alpoim, P.N.; Mota, A.P. Cell-derived microparticles and von Willebrand factor in Brazilian renal transplant recipients. Nephrol. Carlton 2019, 24, 1304-1312. [CrossRef]

47. Alvarez, S.; Suazo, C.; Boltansky, A.; Ursu, M.; Carvajal, D.; Innocenti, G.; Vukusich, A.; Hurtado, M.; Villanueva, S.; Carreño, J.E.; et al. Urinary exosomes as a source of kidney dysfunction biomarker in renal transplantation. Transplant. Proc. 2013, 45, 3719-3723. [CrossRef]

48. Dimuccio, V.; Ranghino, A.; Praticò Barbato, L.; Fop, F.; Biancone, L.; Camussi, G.; Bussolati, B. Urinary CD133+ extracellular vesicles are decreased in kidney transplanted patients with slow graft function and vascular damage. PLoS ONE 2014, 9, e104490. [CrossRef]

49. Sonoda, H.; Yokota-Ikeda, N.; Oshikawa, S.; Kanno, Y.; Yoshinaga, K.; Uchida, K.; Ueda, Y.; Kimiya, K.; Uezono, S.; Ueda, A.; et al. Decreased abundance of urinary exosomal aquaporin-1 in renal ischemia-reperfusion injury. Am. J. Physiol. Ren. Physiol. 2009, 297, F1006-F1016. [CrossRef]

50. Asvapromtada, S.; Sonoda, H.; Kinouchi, M.; Oshikawa, S.; Takahashi, S.; Hoshino, Y.; Sinlapadeelerdkul, T.; Yokota-Ikeda, N.; Matsuzaki, T.; Ikeda, M. Characterization of urinary exosomal release of aquaporin-1 and -2 after renal ischemia-reperfusion in rats. Am. J. Physiol. Ren. Physiol. 2018, 314, F584-F601. [CrossRef]

51. Suthanthiran, M.; Schwartz, J.E.; Ding, R.; Abecassis, M.; Dadhania, D.; Samstein, B.; Knechtle, S.J.; Friedewald, J.; Becker, Y.T.; Sharma, V.K.; et al. Urinary-cell mRNA profile and acute cellular rejection in kidney allografts. N. Engl. J. Med. 2013, 369, 20-31. [CrossRef] [PubMed]

52. Christakoudi, S.; Runglall, M.; Mobillo, P.; Tsui, T.-L.; Duff, C.; Domingo-Vila, C.; Kamra, Y.; Delaney, F.; Montero, R.; Spiridou, A.; et al. Development of a multivariable gene-expression signature targeting T-cell-mediated rejection in peripheral blood of kidney transplant recipients validated in cross-sectional and longitudinal samples. EBioMedicine 2019, 41, 571-583. [CrossRef] [PubMed]

53. Zhang, W.; Yi, Z.; Keung, K.L.; Shang, H.; Wei, C.; Cravedi, P.; Sun, Z.; Xi, C.; Woytovich, C.; Farouk, S.; et al. A Peripheral Blood Gene Expression Signature to Diagnose Subclinical Acute Rejection. J. Am. Soc. Nephrol. 2019, 30, 1481-1494. [CrossRef] [PubMed]

54. Van Loon, E.; Gazut, S.; Yazdani, S.; Lerut, E.; de Loor, H.; Coemans, M.; Noël, L.-H.; Thorrez, L.; Van Lommel, L.; Schuit, F.; et al. Development and validation of a peripheral blood mRNA assay for the assessment of antibody-mediated kidney allograft rejection: A multicentre, prospective study. EBioMedicine 2019, 46, 463-472. [CrossRef] [PubMed] 
55. Friedewald, J.J.; Kurian, S.M.; Heilman, R.L.; Whisenant, T.C.; Poggio, E.D.; Marsh, C.; Baliga, P.; Odim, J.; Brown, M.M.; Ikle, D.N.; et al. Development and clinical validity of a novel blood-based molecular biomarker for subclinical acute rejection following kidney transplant. Am. J. Transplant. 2019, 19, 98-109. [CrossRef] [PubMed]

56. Sigdel, T.; Nguyen, M.; Liberto, J.; Dobi, D.; Junger, H.; Vincenti, F.; Laszik, Z.; Sarwal, M.M. Assessment of 19 Genes and Validation of CRM Gene Panel for Quantitative Transcriptional Analysis of Molecular Rejection and Inflammation in Archival Kidney Transplant Biopsies. Front. Med. 2019, 6, 213. [CrossRef]

57. Roedder, S.; Sigdel, T.; Salomonis, N.; Hsieh, S.; Dai, H.; Bestard, O.; Metes, D.; Zeevi, A.; Gritsch, A.; Cheeseman, J.; et al. The kSORT assay to detect renal transplant patients at high risk for acute rejection: Results of the multicenter AART study. PLoS Med. 2014, 11, e1001759. [CrossRef]

58. Sis, B.; Jhangri, G.S.; Bunnag, S.; Allanach, K.; Kaplan, B.; Halloran, P.F. Endothelial gene expression in kidney transplants with alloantibody indicates antibody-mediated damage despite lack of C4d staining. Am. J. Transplant. 2009, 9, 2312-2323. [CrossRef]

59. Adam, B.A.; Smith, R.N.; Rosales, I.A.; Matsunami, M.; Afzali, B.; Oura, T.; Cosimi, A.B.; Kawai, T.; Colvin, R.B.; Mengel, M. Chronic Antibody-Mediated Rejection in Nonhuman Primate Renal Allografts: Validation of Human Histological and Molecular Phenotypes. Am. J. Transplant. 2017, 17, 2841-2850. [CrossRef]

60. Stites, E.; Renner, B.; Laskowski, J.; Le Quintrec, M.; You, Z.; Freed, B.; Cooper, J.; Jalal, D.; Thurman, J.M. Complement fragments are biomarkers of antibody-mediated endothelial injury. Mol. Immunol. 2020, 118, 142-152. [CrossRef]

61. Mueller, F.B.; Yang, H.; Lubetzky, M.; Verma, A.; Lee, J.R.; Dadhania, D.M.; Xiang, J.Z.; Salvatore, S.P.; Seshan, S.V.; Sharma, V.K.; et al. Landscape of innate immune system transcriptome and acute T cell-mediated rejection of human kidney allografts. JCI Insight 2019, 4. [CrossRef]

62. Hricik, D.E.; Nickerson, P.; Formica, R.N.; Poggio, E.D.; Rush, D.; Newell, K.A.; Goebel, J.; Gibson, I.W.; Fairchild, R.L.; Riggs, M.; et al. Multicenter validation of urinary CXCL9 as a risk-stratifying biomarker for kidney transplant injury. Am. J. Transplant. 2013, 13, 2634-2644. [CrossRef] [PubMed]

63. Rabant, M.; Amrouche, L.; Morin, L.; Bonifay, R.; Lebreton, X.; Aouni, L.; Benon, A.; Sauvaget, V.; Le Vaillant, L.; Aulagnon, F.; et al. Early Low Urinary CXCL9 and CXCL10 Might Predict Immunological Quiescence in Clinically and Histologically Stable Kidney Recipients. Am. J. Transplant. 2016, 16, 1868-1881. [CrossRef] [PubMed]

64. Faddoul, G.; Nadkarni, G.N.; Bridges, N.D.; Goebel, J.; Hricik, D.E.; Formica, R.; Menon, M.C.; Morrison, Y.; Murphy, B.; Newell, K.; et al. Analysis of Biomarkers within the Initial 2 Years Posttransplant and 5-Year Kidney Transplant Outcomes: Results from Clinical Trials in Organ Transplantation-17. Transplantation 2018, 102, 673-680. [CrossRef] [PubMed]

65. Mühlbacher, J.; Doberer, K.; Kozakowski, N.; Regele, H.; Camovic, S.; Haindl, S.; Bond, G.; Haslacher, H.; Eskandary, F.; Reeve, J.; et al. Non-invasive Chemokine Detection: Improved Prediction of Antibody-Mediated Rejection in Donor-Specific Antibody-Positive Renal Allograft Recipients. Front. Med. 2020, 7, 114. [CrossRef] [PubMed]

66. Rabant, M.; Amrouche, L.; Lebreton, X.; Aulagnon, F.; Benon, A.; Sauvaget, V.; Bonifay, R.; Morin, L.; Scemla, A.; Delville, M.; et al. Urinary C-X-C Motif Chemokine 10 Independently Improves the Noninvasive Diagnosis of Antibody-Mediated Kidney Allograft Rejection. J. Am. Soc. Nephrol. 2015, 26, 2840-2851. [CrossRef]

67. Bloom, R.D.; Bromberg, J.S.; Poggio, E.D.; Bunnapradist, S.; Langone, A.J.; Sood, P.; Matas, A.J.; Mehta, S.; Mannon, R.B.; Sharfuddin, A.; et al. Cell-Free DNA and Active Rejection in Kidney Allografts. J. Am. Soc. Nephrol. 2017, 28, 2221-2232. [CrossRef]

68. Huang, E.; Sethi, S.; Peng, A.; Najjar, R.; Mirocha, J.; Haas, M.; Vo, A.; Jordan, S.C. Early clinical experience using donor-derived cell-free DNA to detect rejection in kidney transplant recipients. Am. J. Transplant. 2019, 19, 1663-1670. [CrossRef]

69. Sigdel, T.K.; Archila, F.A.; Constantin, T.; Prins, S.A.; Liberto, J.; Damm, I.; Towfighi, P.; Navarro, S.; Kirkizlar, E.; Demko, Z.P.; et al. Optimizing Detection of Kidney Transplant Injury by Assessment of Donor-Derived Cell-Free DNA via Massively Multiplex PCR. J. Clin. Med. 2018, 8, 19. [CrossRef] 
70. Oellerich, M.; Shipkova, M.; Asendorf, T.; Walson, P.D.; Schauerte, V.; Mettenmeyer, N.; Kabakchiev, M.; Hasche, G.; Gröne, H.-J.; Friede, T.; et al. Absolute quantification of donor-derived cell-free DNA as a marker of rejection and graft injury in kidney transplantation: Results from a prospective observational study. Am. J. Transplant. 2019, 19, 3087-3099. [CrossRef]

71. Jordan, S.C.; Bunnapradist, S.; Bromberg, J.S.; Langone, A.J.; Hiller, D.; Yee, J.P.; Sninsky, J.J.; Woodward, R.N.; Matas, A.J. Donor-derived Cell-free DNA Identifies Antibody-mediated Rejection in Donor Specific Antibody Positive Kidney Transplant Recipients. Transplant. Direct 2018, 4, e379. [CrossRef] [PubMed]

72. Sureshkumar, K.K.; Lyons, S.; Chopra, B. Letter to the Editors. Impact of kidney transplant type and previous transplant on baseline donor-derived cell free DNA. Transpl. Int. 2020. [CrossRef]

73. Jordan, S.C.; Sawinsky, D.; Dholakia, S. Donor-derived cell-free DNA initiates De-Novo Donor Specific Antibody (DSA) responses. Am. J. Transplant. 2019, 19, 404-405.

74. Crespo, E.; Cravedi, P.; Martorell, J.; Luque, S.; Melilli, E.; Cruzado, J.M.; Jarque, M.; Meneghini, M.; Manonelles, A.; Donadei, C.; et al. Posttransplant peripheral blood donor-specific interferon- $\gamma$ enzyme-linked immune spot assay differentiates risk of subclinical rejection and de novo donor-specific alloantibodies in kidney transplant recipients. Kidney Int. 2017, 92, 201-213. [CrossRef]

75. Dholakia, S.; De Vlaminck, I.; Khush, K.K. Adding Insult on Injury: Immunogenic Role for Donor-derived Cell-free DNA? Transplantation 2020. [CrossRef] [PubMed]

76. Kim, K.; Moon, H.; Lee, Y.H.; Seo, J.-W.; Kim, Y.G.; Moon, J.-Y.; Kim, J.S.; Jeong, K.-H.; Lee, T.W.; Ihm, C.-G.; et al. Clinical relevance of cell-free mitochondrial DNA during the early postoperative period in kidney transplant recipients. Sci. Rep. 2019, 9, 18607. [CrossRef] [PubMed]

77. Karahan, G.E.; de Vaal, Y.J.H.; Krop, J.; Wehmeier, C.; Roelen, D.L.; Claas, F.H.J.; Heidt, S. A Memory B Cell Crossmatch Assay for Quantification of Donor-Specific Memory B Cells in the Peripheral Blood of HLA-Immunized Individuals. Am. J. Transplant. 2017, 17, 2617-2626. [CrossRef] [PubMed]

78. Pongpirul, W.; Chancharoenthana, W.; Pongpirul, K.; Leelahavanichkul, A.; Kittikowit, W.; Jutivorakool, K.; Nonthasoot, B.; Avihingsanon, Y.; Eiam-Ong, S.; Praditpornsilpa, K.; et al. B-cell activating factor, a predictor of antibody mediated rejection in kidney transplantation recipients. Nephrol. Carlton 2018, 23, 169-174. [CrossRef]

79. Hricik, D.E.; Augustine, J.; Nickerson, P.; Formica, R.N.; Poggio, E.D.; Rush, D.; Newell, K.A.; Goebel, J.; Gibson, I.W.; Fairchild, R.L.; et al. Interferon Gamma ELISPOT Testing as a Risk-Stratifying Biomarker for Kidney Transplant Injury: Results from the CTOT-01 Multicenter Study. Am. J. Transplant. 2015, 15, 3166-3173. [CrossRef]

80. Gorbacheva, V.; Fan, R.; Fairchild, R.L.; Baldwin, W.M.; Valujskikh, A. Memory CD4 T Cells Induce Antibody-Mediated Rejection of Renal Allografts. J. Am. Soc. Nephrol. 2016, 27, 3299-3307. [CrossRef]

81. Matz, M.; Fabritius, K.; Lorkowski, C.; Dürr, M.; Gaedeke, J.; Durek, P.; Grün, J.R.; Goestemeyer, A.; Bachmann, F.; Wu, K.; et al. Identification of T Cell-Mediated Vascular Rejection after Kidney Transplantation by the Combined Measurement of 5 Specific MicroRNAs in Blood. Transplantation 2016, 100, 898-907. [CrossRef] [PubMed]

82. Trailin, A.V.; Ostapenko, T.I.; Nykonenko, T.N.; Nesterenko, S.N.; Nykonenko, O.S. Peritransplant Soluble CD30 as a Risk Factor for Slow Kidney Allograft Function, Early Acute Rejection, Worse Long-Term Allograft Function, and Patients' Survival. Dis. Markers 2017, 2017, 9264904. [CrossRef] [PubMed]

83. Mirzakhani, M.; Shahbazi, M.; Akbari, R.; Dedinská, I.; Nemati, E.; Mohammadnia-Afrouzi, M. Soluble CD30, the Immune Response, and Acute Rejection in Human Kidney Transplantation: A Systematic Review and Meta-Analysis. Front. Immunol. 2020, 11, 295. [CrossRef] [PubMed]

84. Ashokkumar, C.; Shapiro, R.; Tan, H.; Ningappa, M.; Elinoff, B.; Fedorek, S.; Sun, Q.; Higgs, B.W.; Randhawa, P.; Humar, A.; et al. Allospecific CD154+ T-cytotoxic memory cells identify recipients experiencing acute cellular rejection after renal transplantation. Transplantation 2011, 92, 433-438. [CrossRef]

85. Verma, A.; Muthukumar, T.; Yang, H.; Lubetzky, M.; Cassidy, M.F.; Lee, J.R.; Dadhania, D.M.; Snopkowski, C.; Shankaranarayanan, D.; Salvatore, S.P.; et al. Urinary cell transcriptomics and acute rejection in human kidney allografts. JCI Insight 2020, 5. [CrossRef]

86. Lee, J.R.; Muthukumar, T.; Dadhania, D.; Ding, R.; Sharma, V.K.; Schwartz, J.E.; Suthanthiran, M. Urinary cell mRNA profiles predictive of human kidney allograft status. Immunol. Rev. 2014, 258, 218-240. [CrossRef] 
87. O'Connell, P.J.; Zhang, W.; Menon, M.C.; Yi, Z.; Schröppel, B.; Gallon, L.; Luan, Y.; Rosales, I.A.; Ge, Y.; Losic, B.; et al. Biopsy transcriptome expression profiling to identify kidney transplants at risk of chronic injury: A multicentre, prospective study. Lancet Lond. Engl. 2016, 388, 983-993. [CrossRef]

88. Eikmans, M.; Gielis, E.M.; Ledeganck, K.J.; Yang, J.; Abramowicz, D.; Claas, F.F.J. Non-invasive Biomarkers of Acute Rejection in Kidney Transplantation: Novel Targets and Strategies. Front. Med. 2018, 5, 358. [CrossRef]

89. Jeon, H.J.; Lee, J.-G.; Kim, K.; Jang, J.Y.; Han, S.W.; Choi, J.; Ryu, J.-H.; Koo, T.Y.; Jeong, J.C.; Lee, J.W.; et al. Peripheral blood transcriptome analysis and development of classification model for diagnosing antibody-mediated rejection vs accommodation in ABO-incompatible kidney transplant. Am. J. Transplant. 2020, 20, 112-124. [CrossRef]

90. Marsh, C.L.; Kurian, S.M.; Rice, J.C.; Whisenant, T.C.; David, J.; Rose, S.; Schieve, C.; Lee, D.; Case, J.; Barrick, B.; et al. Application of TruGraf v1: A Novel Molecular Biomarker for Managing Kidney Transplant Recipients with Stable Renal Function. Transplant. Proc. 2019, 51, 722-728. [CrossRef]

91. Peddi, V.R.; Patel, P.S.; Schieve, C.; Rose, S.; First, M.R. Serial Peripheral Blood Gene Expression Profiling to Assess Immune Quiescence in Kidney Transplant Recipients with Stable Renal Function. Ann. Transplant. 2020, 25, e920839. [CrossRef]

92. Hruba, P.; Krejcik, Z.; Stranecky, V.; Maluskova, J.; Slatinska, J.; Gueler, F.; Gwinner, W.; Bräsen, J.H.; Wohlfahrtova, M.; Parikova, A.; et al. Molecular Patterns Discriminate Accommodation and Subclinical Antibody-mediated Rejection in Kidney Transplantation. Transplantation 2019, 103, 909-917. [CrossRef] [PubMed]

93. Halloran, P.F.; Reeve, J.; Akalin, E.; Aubert, O.; Bohmig, G.A.; Brennan, D.; Bromberg, J.; Einecke, G.; Eskandary, F.; Gosset, C.; et al. Real Time Central Assessment of Kidney Transplant Indication Biopsies by Microarrays: The INTERCOMEX Study. Am. J. Transplant. 2017, 17, 2851-2862. [CrossRef] [PubMed]

94. Barner, M.; DeKoning, J.; Kashi, Z.; Halloran, P. Recent Advancements in the Assessment of Renal Transplant Dysfunction with an Emphasis on Microarray Molecular Diagnostics. Clin. Lab. Med. 2018, 38, 623-635. [CrossRef]

95. Wu, H.; Malone, A.F.; Donnelly, E.L.; Kirita, Y.; Uchimura, K.; Ramakrishnan, S.M.; Gaut, J.P.; Humphreys, B.D. Single-Cell Transcriptomics of a Human Kidney Allograft Biopsy Specimen Defines a Diverse Inflammatory Response. J. Am. Soc. Nephrol. 2018, 29, 2069-2080. [CrossRef]

96. Stewart, B.J.; Clatworthy, M.R. Applying single-cell technologies to clinical pathology: Progress in nephropathology. J. Pathol. 2020, 250, 693-704. [CrossRef] [PubMed]

97. Franzin, R.; Stasi, A.; Fiorentino, M.; Stallone, G.; Cantaluppi, V.; Gesualdo, L.; Castellano, G. Inflammaging and Complement System: A Link between Acute Kidney Injury and Chronic Graft Damage. Front. Immunol. 2020, 11, 734. [CrossRef]

98. Bobka, S.; Ebert, N.; Koertvely, E.; Jacobi, J.; Wiesener, M.; Büttner-Herold, M.; Amann, K.; Daniel, C. Is Early Complement Activation in Renal Transplantation Associated with Later Graft Outcome? Kidney Blood Press. Res. 2018, 43, 1488-1504. [CrossRef]

99. Tower, C.M.; Reyes, M.; Nelson, K.; Leca, N.; Kieran, N.; Muczynski, K.; Jefferson, J.A.; Blosser, C.; Kukla, A.; Maurer, D.; et al. Plasma C4d+ Endothelial Microvesicles Increase in Acute Antibody-Mediated Rejection. Transplantation 2017, 101, 2235-2243. [CrossRef]

100. Wang, Z.; Yang, H.; Guo, M.; Han, Z.; Tao, J.; Chen, H.; Ge, Y.; Wang, K.; Tan, R.; Wei, J.-F.; et al. Impact of complement component $3 / 4 / 5$ single nucleotide polymorphisms on renal transplant recipients with antibody-mediated rejection. Oncotarget 2017, 8, 94539-94553. [CrossRef]

101. Lazzeri, E.; Rotondi, M.; Mazzinghi, B.; Lasagni, L.; Buonamano, A.; Rosati, A.; Pradella, F.; Fossombroni, V.; La Villa, G.; Gacci, M.; et al. High CXCL10 expression in rejected kidneys and predictive role of pretransplant serum CXCL10 for acute rejection and chronic allograft nephropathy. Transplantation 2005, 79, 1215-1220. [CrossRef] [PubMed]

102. Rotondi, M.; Netti, G.S.; Lazzeri, E.; Stallone, G.; Bertoni, E.; Chiovato, L.; Grandaliano, G.; Gesualdo, L.; Salvadori, M.; Schena, F.P.; et al. High pretransplant serum levels of CXCL9 are associated with increased risk of acute rejection and graft failure in kidney graft recipients. Transpl. Int. 2010, 23, 465-475. [CrossRef] [PubMed]

103. Hirt-Minkowski, P.; De Serres, S.A.; Ho, J. Developing renal allograft surveillance strategies-Urinary biomarkers of cellular rejection. Can. J. Kidney Health Dis. 2015, 2, 28. [CrossRef] [PubMed] 
104. Schiffer, L.; Wiehler, F.; Bräsen, J.H.; Gwinner, W.; Greite, R.; Kreimann, K.; Thorenz, A.; Derlin, K.; Teng, B.; Rong, S.; et al. Chemokine CXCL13 as a New Systemic Biomarker for B-Cell Involvement in Acute T Cell-Mediated Kidney Allograft Rejection. Int. J. Mol. Sci. 2019, 20, 2552. [CrossRef]

105. Katou, S.; Globke, B.; Morgul, M.H.; Vogel, T.; Struecker, B.; Otto, N.M.; Reutzel-Selke, A.; Marksteiner, M.; Brockmann, J.G.; Pascher, A.; et al. Urinary Biomarkers $\alpha$-GST and $\pi$-GST for Evaluation and Monitoring in Living and Deceased Donor Kidney Grafts. J. Clin. Med. 2019, 8, 1899. [CrossRef] [PubMed]

106. Kim, S.-Y.; Kim, B.K.; Gwon, M.-R.; Seong, S.J.; Ohk, B.; Kang, W.Y.; Lee, H.W.; Jung, H.-Y.; Cho, J.-H.; Chung, B.H.; et al. Urinary metabolomic profiling for noninvasive diagnosis of acute T cell-mediated rejection after kidney transplantation. J. Chromatogr. B 2019, 1118, 157-163. [CrossRef] [PubMed]

107. Shen, J.; Zhou, Y.; Chen, Y.; Li, X.; Lei, W.; Ge, J.; Peng, W.; Wu, J.; Liu, G.; Yang, G.; et al. Dynamics of early post-operative plasma ddcf DNA levels in kidney transplantation: A single-center pilot study. Transpl. Int. 2019, 32, 184-192. [CrossRef]

108. Bloom, R.D. Using (cell-free) DNA to incriminate rejection as the cause of kidney allograft dysfunction: Do we have a verdict? Am. J. Transplant. 2019, 19, 1609-1610. [CrossRef]

109. Thongprayoon, C.; Vaitla, P.; Craici, I.M.; Leeaphorn, N.; Hansrivijit, P.; Salim, S.A.; Bathini, T.; Cabeza Rivera, F.H.; Cheungpasitporn, W. The Use of Donor-Derived Cell-Free DNA for Assessment of Allograft Rejection and Injury Status. J. Clin. Med. 2020, 9, 1480. [CrossRef]

110. Stites, E.; Kumar, D.; Olaitan, O.; Swanson, S.H.; Leca, N.; Weir, M.; Bromberg, J.; Melancon, J.; Agha, I.; Fattah, H.; et al. High levels of dd-cf DNA identify patients with TCMR 1A and borderline allograft rejection at elevated risk of graft injury. Am. J. Transplant. 2020. [CrossRef]

111. Oweira, H.; Khajeh, E.; Mohammadi, S.; Ghamarnejad, O.; Daniel, V.; Schnitzler, P.; Golriz, M.; Mieth, M.; Morath, C.; Zeier, M.; et al. Pre-transplant CD200 and CD200R1 concentrations are associated with post-transplant events in kidney transplant recipients. Med. Baltim. 2019, 98, e17006. [CrossRef] [PubMed]

112. Lemerle, M.; Garnier, A.-S.; Planchais, M.; Brilland, B.; Subra, J.-F.; Blanchet, O.; Blanchard, S.; Croue, A.; Duveau, A.; Augusto, J.-F. CD45RC Expression of Circulating CD8(+) T Cells Predicts Acute Allograft Rejection: A Cohort Study of 128 Kidney Transplant Patients. J. Clin. Med. 2019, 8, 1147. [CrossRef] [PubMed]

113. Zhang, R. Donor-Specific Antibodies in Kidney Transplant Recipients. Clin. J. Am. Soc. Nephrol. 2018, 13, 182-192. [CrossRef] [PubMed]

114. Wehmeier, C.; Karahan, G.E.; Heidt, S. HLA-specific memory B-cell detection in kidney transplantation: Insights and future challenges. Int. J. Immunogenet. 2020, 47, 227-234. [CrossRef] [PubMed]

115. Zhang, X.; Reinsmoen, N.L. Impact and production of Non-HLA-specific antibodies in solid organ transplantation. Int. J. Immunogenet. 2020, 47, 235-242. [CrossRef]

116. Reindl-Schwaighofer, R.; Heinzel, A.; Gualdoni, G.A.; Mesnard., L.; Claas, F.H.J.; Oberbauer, R. Novel insights into non-HLA alloimmunity in kidney transplantation. Transpl. Int. 2020, 33, 5-17. [CrossRef]

117. Delville, M.; Lamarthée, B. Early Acute Microvascular Kidney Transplant Rejection in the Absence of Anti-HLA Antibodies Is Associated with Preformed IgG Antibodies against Diverse Glomerular Endothelial Cell Antigens. J. Am. Soc. Nephrol. 2019, 30, 692-709. [CrossRef]

118. Cardinal, H.; Dieudé, M.; Hébert, M.J. The Emerging Importance of Non-HLA Autoantibodies in Kidney Transplant Complications. J. Am. Soc. Nephrol. 2017, 28, 400-406. [CrossRef]

119. Dragun, D.; Catar, R.; Aurelie, P. Non-HLA antibodies against endothelial targets bridging allo-and autoimmunity. Kidney Int. 2016, 90, 280-288. [CrossRef]

120. Philogene, M.C.; Johnson, T.; Vaught, A.J.; Zakaria, S.; Fedarko., N. Antibodies against Angiotensin II Type 1 and Endothelin A Receptors: Relevance and pathogenicity. Hum. Immunol. 2019, 80, 561-567. [CrossRef]

121. Sas-Strózik, A.; Krajewska, M.; Banasik, M. The significance of angiotensin II type 1 receptor (AT1 receptor) in renal transplant injury. Adv. Clin. Exp. Med. 2020, 29, 629-633. [CrossRef] [PubMed]

122. Shinaeu, Y.; Hee, J.H.; Kyo, W.L.; Park, J.B.; Kim, S.; Huh, W.; Jang, H.R.; Kwon, G.Y.; Moon, H.H.; Kang, S. Pre-Transplant Angiotensin II Type 1 Receptor Antibodies and Anti-Endothelial Cell Antibodies Predict Graft Function and Allograft Rejection in a Low-Risk Kidney Transplantation Setting. Ann. Lab. Med. 2020, 40, 398-408. [CrossRef]

123. Pinelli, D.F.; Friedewald, J.J. Assessing the potential of angiotensin II type 1 receptor and donor specific anti-endothelial cell antibodies to predict long-term kidney graft outcome. Hum. Immunol. 2017, 78, 421-427. [CrossRef] [PubMed] 
124. Philogene, M.C.; Zhou, S. Pre-transplant Screening for Non-HLA Antibodies: Who should be Tested? Hum. Immunol. 2018, 79, 195-202. [CrossRef] [PubMed]

125. Lim, M.A.; Palmer, M.; Trofe-Clark, J.; Bloom, R.D.; Jackson, A.; Philogene, M.C.; Kamoun, M. Histopathologic changes in anti-angiotensin II type 1 receptor antibody-positive kidney transplant recipients with acute rejection and no donor specific HLA antibodies. Hum. Immunol. 2017, 78, 350-356. [CrossRef] [PubMed]

126. Divanyan, T.; Acosta, E.; Patel, D.; Constantino, D.; Lopez-Soler, R.I. Anti-vimentin antibodies in transplant and disease. Hum. Immunol. 2019, 80, 602-607. [CrossRef]

127. Dieudé, M.; Cardinal, H.; Hébert, M.-J. Injury derived autoimmunity: Anti-perlecan/LG3 antibodies in transplantation. Hum. Immunol. 2019, 80, 608-613. [CrossRef]

128. Riesco, L.; Irure, J.; Rodrigo, E.; Guiral, S.; Ruiz, J.C.; Gómez, J.; Hoyos, M.L.; San Segundo, D. Anti-perlecan antibodies and acute humoral rejection in hypersensitized patients without forbidden HLA specificities after kidney transplantation. Transpl. Immunol. 2019, 52, 53-56. [CrossRef]

129. Padet, L.; Dieudé, M.; Karakeussian-Rimbaud, A.; Yang, B.; Turgeon, J.; Jean-Cailhier, F.; Cardinal, H.; Hébert, M.-J. New insights into immune mechanisms of antiperlecan/LG3 antibody production: Importance of T cells and innate B1 cells. Am. J. Transplant. 2019, 19, 699-712. [CrossRef]

130. Yang, B.; Dieudé, M.; Hamelin, K.; Hénault-Rondeau, M.; Patey, N.; Turgeon, J.; Lan, S.; Pomerleau, L.; Quesnel, M.; Peng, J.; et al. Anti-LG3 Antibodies Aggravate Renal Ischemia-Reperfusion Injury and Long-Term Renal Allograft Dysfunction. Am. J. Transplant. 2016, 16, 3416-3429. [CrossRef]

131. Jackson, A.M.; Sigdel, T.K.; Delville, M.; Hsieh, S.; Dai, H.; Bagnasco, S.; Montgomery, R.A.; Sarwal, M.M. Endothelial cell antibodies associated with novel targets and increased rejection. J. Am. Soc. Nephrol. 2015, 26, 1161-1171. [CrossRef] [PubMed]

132. Guo, X.; Hu, J.; Luo, W.; Luo, Q.; Guo, J.; Tian, F.; Ming, Y.; Zou, Y. Analysis of Sera of Recipients with Allograft Rejection Indicates that Keratin 1 Is the Target of Anti-Endothelial Antibodies. Immunol. Res. 2017, 2017, 8679841. [CrossRef] [PubMed]

133. Sánchez-Zapardiel, E.; Mancebo, E.; Díaz-Ordoñez, M.; de Jorge-Huerta, L.; Ruiz-Martínez, L.; Serrano, A.; Castro-Panete, M.J.; Utrero-Rico, A.; de Andrés, A.; Morales, J.M.; et al. Isolated de Novo Antiendothelial Cell Antibodies and Kidney Transplant Rejection. Am. J. Kidney Dis. 2016, 68, 933-943. [CrossRef] [PubMed]

134. Jackson, A.M.; Delville, M.; Lamarthée, B.; Anglicheau, D. Sensitization to endothelial cell antigens: Unraveling the cause or effect paradox. Hum. Immunol. 2019, 80, 614-620. [CrossRef]

135. Angaswamy, N.; Klein, C.; Tiriveedhi, V.; Gaut, J.; Anwar, S.; Rossi, A.; Phelan, D.; Wellen, J.R.; Shenoy, S.; Chapman, W.C.; et al. Immune responses to collagen-IV and fibronectin in renal transplant recipients with transplant glomerulopathy. Am. J. Transplant. 2014, 14, 685-693. [CrossRef]

136. Gunasekaran, M.; Vachharajani, N.; Gaut, J.P.; Maw, T.T.; Delos Santos, R.; Shenoy, S.; Chapman, W.C.; Wellen, J.; Mohanakumar, T. Development of immune response to tissue-restricted self-antigens in simultaneous kidney-pancreas transplant recipients with acute rejection. Clin. Transplant. 2017, $31,8$. [CrossRef]

137. Soma, O.; Hatakeyama, S.; Yoneyama, T.; Saito, M.; Sasaki, H.; Tobisawa, Y.; Noro, D.; Suzuki, Y.; Tanaka, M.; Nishimura, S.-I.; et al. Serum N-glycan profiling can predict biopsy-proven graft rejection after living kidney transplantation. Clin. Exp. Nephrol. 2020, 24, 174-184. [CrossRef]

138. Maehana, T.; Tanaka, T.; Kitamura, H.; Fukuzawa, N.; Ishida, H.; Harada, H.; Tanabe, K.; Masumori, N. Heat Shock Protein $90 \alpha$ Is a Potential Serological Biomarker of Acute Rejection after Renal Transplantation. PLoS ONE 2016, 11, e0162942. [CrossRef]

139. Barbas, A.S.; Lin, L.; McRae, M.; MacDonald, A.L.; Truong, T.; Yang, Y.; Brennan, T.V. Heparan sulfate is a plasma biomarker of acute cellular allograft rejection. PLoS ONE 2018, 13, e0200877. [CrossRef]

140. Kim, S.C.; Page, E.K.; Knechtle, S.J. Urine proteomics in kidney transplantation. Transplant. Rev. 2014, 28, 15-20. [CrossRef]

141. Perez, J.D.; Sakata, M.M.; Colucci, J.A.; Spinelli, G.A.; Felipe, C.R.; Carvalho, V.M.; Cardozo, K.H.M.; Medina-Pestana, J.O.; Tedesco-Silva, H.J.; Schor, N.; et al. Plasma proteomics for the assessment of acute renal transplant rejection. Life Sci. 2016, 158, 111-120. [CrossRef] [PubMed]

142. Zhang, H.; Huang, E.; Kahwaji, J.; Nast, C.C.; Li, P.; Mirocha, J.; Thomas, D.L.; Ge, S.; Vo, A.A.; Jordan, S.C.; et al. Plasma Exosomes from HLA-Sensitized Kidney Transplant Recipients Contain mRNA Transcripts Which Predict Development of Antibody-Mediated Rejection. Transplantation 2017, 101, 2419-2428. [CrossRef] [PubMed] 
143. Qamri, Z.; Pelletier, R.; Foster, J.; Kumar, S.; Momani, H.; Ware, K.; Von Visger, J.; Satoskar, A.; Nadasdy, T.; Brodsky, S.V. Early posttransplant changes in circulating endothelial microparticles in patients with kidney transplantation. Transpl. Immunol. 2014, 31, 60-64. [CrossRef] [PubMed]

144. Sigdel, T.K.; Ng, Y.W.; Lee, S.; Nicora, C.D.; Qian, W.-J.; Smith, R.D.; Camp, D.G., 2nd; Sarwal, M.M. Perturbations in the urinary exosome in transplant rejection. Front. Med. 2014, 1, 57. [CrossRef]

145. Lim, J.-H.; Lee, C.-H.; Kim, K.Y.; Jung, H.-Y.; Choi, J.-Y.; Cho, J.-H.; Park, S.-H.; Kim, Y.-L.; Baek, M.-C.; Park, J.B.; et al. Novel urinary exosomal biomarkers of acute T cell-mediated rejection in kidney transplant recipients: A cross-sectional study. PLoS ONE 2018, 13, e0204204. [CrossRef]

146. Park, J.; Lin, H.-Y.; Assaker, J.P.; Jeong, S.; Huang, C.-H.; Kurdi, A.; Lee, K.; Fraser, K.; Min, C.; Eskandari, S.; et al. Integrated Kidney Exosome Analysis for the Detection of Kidney Transplant Rejection. ACS Nano 2017, 11, 11041-11046. [CrossRef]

147. Yang, C.; Qi, R.; Yang, B. Pathogenesis of Chronic Allograft Dysfunction Progress to Renal Fibrosis. Adv. Exp. Med. Biol. 2019, 1165, 101-116. [CrossRef]

148. Sellarés, J.; de Freitas, D.G.; Mengel, M.; Reeve, J.; Einecke, G.; Sis, B.; Hidalgo, L.G.; Famulski, K.; Matas, A.; Halloran, P.F. Understanding the causes of kidney transplant failure: The dominant role of antibody-mediated rejection and nonadherence. Am. J. Transplant. 2012, 12, 388-399. [CrossRef]

149. Castellano, G.; Intini, A.; Stasi, A.; Divella, C.; Gigante, M.; Pontrelli, P.; Franzin, R.; Accetturo, M.; Zito, A.; Fiorentino, M.; et al. Complement Modulation of Anti-Aging Factor Klotho in Ischemia/Reperfusion Injury and Delayed Graft Function. Am. J. Transplant. 2016, 16, 325-333. [CrossRef]

150. Humphreys, B.D. Mechanisms of Renal Fibrosis. Annu. Rev. Physiol. 2018, 80, 309-326. [CrossRef]

151. Yiu, W.H.; Li, R.X.; Wong, D.W.L.; Wu, H.J.; Chan, K.W.; Chan, L.Y.Y.; Leung, J.C.K.; Lai, K.N.; Sacks, S.H.; Zhou, W.; et al. Complement C5a inhibition moderates lipid metabolism and reduces tubulointerstitial fibrosis in diabetic nephropathy. Nephrol. Dial. Transplant. 2018, 33, 1323-1332. [CrossRef] [PubMed]

152. Tang, Z.; Lu, B.; Hatch, E.; Sacks, S.H.; Sheerin, N.S. C3a mediates epithelial-to-mesenchymal transition in proteinuric nephropathy. J. Am. Soc. Nephrol. 2009, 20, 593-603. [CrossRef] [PubMed]

153. Xavier, S.; Sahu, R.K.; Landes, S.G.; Yu, J.; Taylor, R.P.; Ayyadevara, S.; Megyesi, J.; Stallcup, W.B.; Duffield, J.S.; Reis, E.S.; et al. Pericytes and immune cells contribute to complement activation in tubulointerstitial fibrosis. Am. J. Physiol. Ren. Physiol. 2017, 312, F516-F532. [CrossRef]

154. Modena, B.D.; Kurian, S.M.; Gaber, L.W.; Waalen, J.; Su, A.I.; Gelbart, T.; Mondala, T.S.; Head, S.R.; Papp, S.; Heilman, R.; et al. Gene Expression in Biopsies of Acute Rejection and Interstitial Fibrosis/Tubular Atrophy Reveals Highly Shared Mechanisms That Correlate with Worse Long-Term Outcomes. Am. J. Transplant. 2016, 16, 1982-1998. [CrossRef] [PubMed]

155. Mas, V.; Maluf, D.; Archer, K.; Yanek, K.; Mas, L.; King, A.; Gibney, E.; Massey, D.; Cotterell, A.; Fisher, R.; et al. Establishing the molecular pathways involved in chronic allograft nephropathy for testing new noninvasive diagnostic markers. Transplantation 2007, 83, 448-457. [CrossRef] [PubMed]

156. Li, L.; Greene, I.; Readhead, B.; Menon, M.C.; Kidd, B.A.; Uzilov, A.V.; Wei, C.; Philippe, N.; Schroppel, B.; He, J.C.; et al. Novel Therapeutics Identification for Fibrosis in Renal Allograft Using Integrative Informatics Approach. Sci. Rep. 2017, 7, 39487. [CrossRef]

157. Zununi Vahed, S.; Omidi, Y.; Ardalan, M.; Samadi, N. Dysregulation of urinary miR-21 and miR-200b associated with interstitial fibrosis and tubular atrophy (IFTA) in renal transplant recipients. Clin. Biochem. 2017, 50, 32-39. [CrossRef]

158. Zununi Vahed, S.; Poursadegh Zonouzi, A.; Mahmoodpoor, F.; Samadi, N.; Ardalan, M.; Omidi, Y. Circulating miR-150, miR-192, miR-200b, and miR-423-3p as Non-invasive Biomarkers of Chronic Allograft Dysfunction. Arch. Med. Res. 2017, 48, 96-104. [CrossRef]

159. Zununi Vahed, S.; Poursadegh Zonouzi, A.; Ghanbarian, H.; Ghojazadeh, M.; Samadi, N.; Omidi, Y.; Ardalan, M. Differential expression of circulating miR-21, miR-142-3p and miR-155 in renal transplant recipients with impaired graft function. Int. Urol. Nephrol. 2017, 49, 1681-1689. [CrossRef]

160. Matz, M.; Heinrich, F.; Lorkowski, C.; Wu, K.; Klotsche, J.; Zhang, Q.; Lachmann, N.; Durek, P.; Budde, K.; Mashreghi, M.-F. MicroRNA regulation in blood cells of renal transplanted patients with interstitial fibrosis/tubular atrophy and antibody-mediated rejection. PLoS ONE 2018, 13, e0201925. [CrossRef]

161. Granata, S.; Benedetti, C.; Gambaro, G.; Zaza, G. Kidney allograft fibrosis: What we learned from latest translational research studies. J. Nephrol. 2020. [CrossRef] [PubMed] 
162. Matas, A.J.; Helgeson, E.S.; Gaston, R.; Cosio, F.; Mannon, R.; Kasiske, B.L.; Hunsicker, L.; Gourishankar, S.; Rush, D.; Michael Cecka, J.; et al. Inflammation in areas of fibrosis: The DeKAF prospective cohort. Am. J. Transplant. 2020. [CrossRef] [PubMed]

163. Maluf, D.G.; Dumur, C.I.; Suh, J.L.; Scian, M.J.; King, A.L.; Cathro, H.; Lee, J.K.; Gehrau, R.C.; Brayman, K.L.; Gallon, L.; et al. The urine microRNA profile may help monitor post-transplant renal graft function. Kidney Int. 2014, 85, 439-449. [CrossRef] [PubMed]

164. Bontha, S.V.; Maluf, D.G.; Archer, K.J.; Dumur, C.I.; Dozmorov, M.G.; King, A.L.; Akalin, E.; Mueller, T.F.; Gallon, L.; Mas, V.R. Effects of DNA Methylation on Progression to Interstitial Fibrosis and Tubular Atrophy in Renal Allograft Biopsies: A Multi-Omics Approach. Am. J. Transplant. 2017, 17, 3060-3075. [CrossRef] [PubMed]

165. Kalluri, R.; Weinberg, R.A. The basics of epithelial-mesenchymal transition. J. Clin. Investig. 2009, 119, 1420-1428. [CrossRef] [PubMed]

166. Srivastava, S.M.; Hedayat, A.F.; Kanasaki, K.; Goodwin, G.E. MicroRNA Crosstalk Influences Epithelial-to-Mesenchymal, Endothelial-to-Mesenchymal, and Macrophage-to-Mesenchymal Transitions in the Kidney. Front. Pharmacol. 2019, 10, 904. [CrossRef]

167. Alfieri, C.; Regalia, A.; Moroni, G.; Cresseri, D.; Zanoni, F.; Ikehata, M.; Simonini, P.; Rastaldi, M.P.; Tripepi, G.; Zoccali., C.; et al. Novel markers of graft outcome in a cohort of kidney transplanted patients: A cohort observational study. J. Nephrol. 2019, 32, 139-150. [CrossRef]

168. Zhou, J.; Cheng, H.; Wang, Z.; Chen, H.; Suo, C.; Zhang, H.; Zhang, J.; Yang, Y.; Geng, L.; Gu, M.; et al. Bortezomib attenuates renal interstitial fibrosis in kidney transplantation via regulating the EMT induced by TNF- $\alpha$-Smurf1-Akt-mTOR-P70S6K pathway. J. Cell. Mol. Med. 2019, 23, 5390-5402. [CrossRef]

169. Hazzan, M.; Hertig, A.; Buob, D.; Copin, M.-C.; Noël, C.; Rondeau, E.; XuDubois, Y.C. Epithelial-to-mesenchymal transition predicts cyclosporine nephrotoxicity in renal transplant recipients. J. Am. Soc. Nephrol. 2011, 22, 1375-1381. [CrossRef]

170. Sosa Peña, M.D.P.; Lopez-Soler, R.; Melendez, J.A. Senescence in chronic allograft nephropathy. Am. J. Physiol. Ren. Physiol. 2018, 315, F880-F889. [CrossRef]

171. Mezni, I.; Galichon, P.; Bacha, M.M.; XuDubois, Y.C.; Sfar, I.; Buob, D.; Benbouzid, S.; Goucha, R.; Gorgi, Y.; Abderrhaim, E.; et al. Urinary mRNA analysis of biomarkers to epithelial mesenchymal transition of renal allograft. Nephrol. Ther. 2018, 14, 153-161. [CrossRef] [PubMed]

172. Galichon, P.; XuDubois, Y.C.; Buob, D.; Tinel, C.; Anglicheau, D.; Benbouzid, S.; Dahan, K.; Ouali, N.; Hertig, A.; Brocheriou, I.; et al. Urinary transcriptomics reveals patterns associated with subclinical injury of the renal allograft. Biomark. Med. 2018, 12, 427-438. [CrossRef] [PubMed]

173. Xu-Dubois, Y.-C.; Peltier, J.; Brocheriou, I.; Suberbielle-Boissel, C.; Djamali, A.; Reese, S.; Mooney, N.; Keuylian, Z.; Lion, J.; Ouali, N.; et al. Markers of Endothelial-to-Mesenchymal Transition: Evidence for Antibody-Endothelium Interaction during Antibody-Mediated Rejection in Kidney Recipients. J. Am. Soc. Nephrol. 2016, 27, 324-332. [CrossRef]

174. Wang, Z.; Han, Z.; Tao, J.; Wang, J.; Liu, X.; Zhou, W.; Xu, Z.; Zhao, C.; Wang, Z.; Tan, R.; et al. Role of endothelial-to-mesenchymal transition induced by TGF- $\beta 1$ in transplant kidney interstitial fibrosis. J. Cell. Mol. Med. 2017, 21, 2359-2369. [CrossRef]

175. Glover, E.K.; Jordan, N.; Sheerin, N.S.; Ali, S. Regulation of Endothelial-to-Mesenchymal Transition by MicroRNAs in Chronic Allograft Dysfunction. Transplantation 2019, 103, e64-e73. [CrossRef] [PubMed]

176. Fernando, M.; Peake, P.W.; Endre, Z.H. Biomarkers of calcineurin inhibitor nephrotoxicity in transplantation. Biomark. Med. 2014, 8, 1247-1262. [CrossRef] [PubMed]

177. Xia, T.; Fu, S.; Wang, Q.; Wen, Y.; Chan, S.-A.; Zhu, S.; Gao, S.; Tao, X.; Zhang, F.; Chen, W. Targeted metabolomic analysis of 33 amino acids and biogenic amines in human urine by ion-pairing HPLC-MS/MS: Biomarkers for tacrolimus nephrotoxicity after renal transplantation. Biomed. Chromatogr. BMC 2018, 32, e4198. [CrossRef] [PubMed]

178. Gacka, E.; Życzkowski, M.; Bogacki, R.; Paradysz, A.; Hyla-Klekot, L. The Usefulness of Determining Neutrophil Gelatinase-Associated Lipocalin Concentration Excreted in the Urine in the Evaluation of Cyclosporine A Nephrotoxicity in Children with Nephrotic Syndrome. Dis. Markers 2016, 2016, 6872149. [CrossRef]

179. Wu, Z.; Xu, Q.; Qiu, X.; Xu, L.; Jiao, Z.; Zhang, M.; Zhong, M. FKBP1A rs6041749 polymorphism is associated with allograft function in renal transplant patients. Eur. J. Clin. Pharmacol. 2019, 75, 33-40. [CrossRef] 
180. Carlos, C.P.; Sonehara, N.M.; Oliani, S.M.; Burdmann, E.A. Predictive usefulness of urinary biomarkers for the identification of cyclosporine. PLoS ONE 2014, 9, e103660. [CrossRef]

181. Cui, Y.; Huang, Q.; Auman, J.T.; Knight, B.; Jin, X.; Blanchard, K.T.; Chou, J.; Jayadev, S.; Paules, R.S. Genomic-derived markers for early detection of calcineurin inhibitor immunosuppressant-mediated nephrotoxicity. Toxicol. Sci. 2011, 124, 23-34. [CrossRef] [PubMed]

182. Masutani, K. Viral infections directly involved in kidney allograft function. Nephrol. Carlton 2018, 23 (Suppl. 2), 31-37. [CrossRef]

183. Kim, M.H.; Lee, Y.H.; Seo, J.-W.; Moon, H.; Kim, J.S.; Kim, Y.G.; Jeong, K.-H.; Moon, J.-Y.; Lee, T.W.; Ihm, C.-G.; et al. Urinary exosomal viral microRNA as a marker of BK virus nephropathy in kidney transplant recipients. PLoS ONE 2017, 12, e0190068. [CrossRef] [PubMed]

184. Ho, J.; Schaub, S.; Wiebe, C.; Gao, A.; Wehmeier, C.; Koller, M.T.; Hirsch, H.H.; Hopfer, H.; Nickerson, P.; Hirt-Minkowski, P. Urinary CXCL10 Chemokine Is Associated with Alloimmune and Virus Compartment-Specific Renal Allograft Inflammation. Transplantation 2018, 102, 521-529. [CrossRef] [PubMed]

185. Dvir, R.; Paloschi, V.; Canducci, F.; Dell'Antonio, G.; Racca, S.; Caldara, R.; Pantaleo, G.; Clementi, M.; Secchi, A. IL28B rs12979860 genotype as a predictor marker of progression to BKVirus Associated nephropathy, after kidney transplantation. Sci. Rep. 2017, 7, 6746. [CrossRef] [PubMed]

186. Pan, L.; Lyu, Z.; Adam, B.; Zeng, G.; Wang, Z.; Huang, Y.; Abedin, Z.; Randhawa, P. Polyomavirus BK Nephropathy-Associated Transcriptomic Signatures: A Critical Reevaluation. Transplant. Direct 2018, 4, e339. [CrossRef]

187. Verhoeven, J.G.H.P.; Boer, K.; Van Schaik, R.H.N.; Manintveld, O.C.; Huibers, M.M.H.; Baan, C.C.; Hesselink, D.A. Liquid Biopsies to Monitor Solid Organ Transplant Function: A Review of New Biomarkers. Ther. Drug Monit. 2018, 40, 515-525. [CrossRef]

188. Peeters, L.E.J.; Andrews, L.M.; Hesselink, D.A.; de Winter, B.C.M.; van Gelder, T. Personalized immunosuppression in elderly renal transplant recipients. Pharmacol. Res. 2018, 130, 303-307. [CrossRef]

189. Newell, K.A.; Adams, A.B.; Turka, L.A. Biomarkers of operational tolerance following kidney transplantation-The immune tolerance network studies of spontaneously tolerant kidney transplant recipients. Hum. Immunol. 2018, 79, 380-387. [CrossRef]

190. Massart, A.; Ghisdal, L.; Abramowicz, M.; Abramowicz, D. Operational tolerance in kidney transplantation and associated biomarkers. Clin. Exp. Immunol. 2017, 189, 138-157. [CrossRef]

191. Newell, K.A.; Asare, A.; Kirk, A.D.; Gisler, T.D.; Bourcier, K.; Suthanthiran, M.; Burlingham, W.J.; Marks, W.H.; Sanz, I.; Lechler, R.I.; et al. Identification of a B cell signature associated with renal transplant tolerance in humans. J. Clin. Investig. 2010, 120, 1836-1847. [CrossRef] [PubMed]

192. Danger, R.; Chesneau, M.; Paul, C.; Guérif, P.; Durand, M.; Newell, K.A.; Kanaparthi, S.; Turka, L.A.; Soulillou, J.-P.; Houlgatte, R.; et al. A composite score associated with spontaneous operational tolerance in kidney transplant recipients. Kidney Int. 2017, 91, 1473-1481. [CrossRef] [PubMed]

193. Kurian, S.M.; Whisenant, T.C.; Mathew, J.M.; Miller, J.; Leventhal, J.R. Transcriptomic studies in tolerance: Lessons learned and the path forward. Hum. Immunol. 2018, 79, 395-401. [CrossRef] [PubMed]

194. Girmanova, E.; Hruba, P.; Viklicky, O. Circulating biomarkers of tolerance. Transplant. Rev. 2015, $29,68-72$. [CrossRef] [PubMed]

195. Bontha, S.V.; Fernandez-Piñeros, A.; Maluf, D.G.; Mas, V.R. Messengers of tolerance. Hum. Immunol. 2018, 79, 362-372. [CrossRef]

196. Niel, O.; Bastard, P. Artificial Intelligence in Nephrology: Core Concepts, Clinical Applications, and Perspectives. Am. J. Kidney Dis. 2019, 74, 803-810. [CrossRef]

197. Briganti, G.; Le Moine, O. Artificial Intelligence in Medicine: Today and Tomorrow. Front. Med. 2020, 7, 27. [CrossRef]

198. Hummel, A.D.; Maciel, R.F.; Sousa, F.S.; Cohrs, F.M.; Falcão, A.E.J.; Teixeira, F.; Baptista, R.; Mancini, F.; da Costa, T.M.; Alves, D.; et al. Artificial intelligence techniques: Predicting necessity for biopsy in renal transplant recipients suspected of acute cellular rejection or nephrotoxicity. Transplant. Proc. 2011, 43, 1343-1344. [CrossRef] 
199. Niel, O.; Bastard, P. Artificial intelligence improves estimation of tacrolimus area under the concentration over time curve in renal transplant recipients. Transpl. Int. 2018, 31, 940-941. [CrossRef]

200. Aubert, O.; Higgins, S.; Bouatou, Y.; Yoo, D.; Raynaud, M.; Viglietti, D.; Rabant, M.; Hidalgo, L.; Glotz, D.; Legendre, C.; et al. Archetype Analysis Identifies Distinct Profiles in Renal Transplant Recipients with Transplant Glomerulopathy Associated with Allograft Survival. J. Am. Soc. Nephrol. 2019, 30, 625-639. [CrossRef] 